IZA DP No. 9776

The Shifting Job Tenure Distribution

Henry R. Hyatt

James R. Spletzer

February 2016

Forschungsinstitut

zur Zukunft der Arbeit

Institute for the Study

of Labor 


\title{
The Shifting Job Tenure Distribution
}

\author{
Henry R. Hyatt \\ U.S. Census Bureau \\ and IZA
}

James R. Spletzer

U.S. Census Bureau

and IZA

\section{Discussion Paper No. 9776 \\ February 2016}

\author{
IZA \\ P.O. Box 7240 \\ 53072 Bonn \\ Germany \\ Phone: +49-228-3894-0 \\ Fax: +49-228-3894-180 \\ E-mail: iza@iza.org
}

\begin{abstract}
Any opinions expressed here are those of the author(s) and not those of IZA. Research published in this series may include views on policy, but the institute itself takes no institutional policy positions. The IZA research network is committed to the IZA Guiding Principles of Research Integrity.

The Institute for the Study of Labor (IZA) in Bonn is a local and virtual international research center and a place of communication between science, politics and business. IZA is an independent nonprofit organization supported by Deutsche Post Foundation. The center is associated with the University of Bonn and offers a stimulating research environment through its international network, workshops and conferences, data service, project support, research visits and doctoral program. IZA engages in (i) original and internationally competitive research in all fields of labor economics, (ii) development of policy concepts, and (iii) dissemination of research results and concepts to the interested public.
\end{abstract}

IZA Discussion Papers often represent preliminary work and are circulated to encourage discussion. Citation of such a paper should account for its provisional character. A revised version may be available directly from the author. 
IZA Discussion Paper No. 9776

February 2016

\section{ABSTRACT \\ The Shifting Job Tenure Distribution*}

There has been a shift in the U.S. job tenure distribution toward longer-duration jobs since 2000. This change is apparent both in the tenure supplements to the Current Population Survey and the Longitudinal Employer-Household Dynamics matched employer-employee data. A substantial portion of these changes are caused by the ageing of the workforce and the decline in the entry rate of new employer businesses. We show that the tenure distribution is a function of historical hiring rates and tenure-specific separation rates, and we use this framework to show that the shift in the tenure distribution is accounted for primarily by declines in the hiring rate, which are concentrated in the labor market downturns associated with the 2001 and 2007-2009 recessions. We also find that the increase in average real earnings since 2007 is less than what would be predicted by the shift toward longer-tenure jobs; this reflects declines in tenure-held-constant real earnings. Regression estimates of the returns to job tenure provide no evidence that the shift in the job tenure distribution is being driven by better matches between workers and employers.

JEL Classification: J10, J21, J31

Keywords: $\quad$ tenure, hires and separations, earnings

Corresponding author:

James R. Spletzer

Center for Economic Studies

U.S. Census Bureau

4600 Silver Hill Road

Washington, DC 20233

USA

E-mail: James.R.Spletzer@census.gov

\footnotetext{
* Any opinions and conclusions expressed herein are those of the authors and do not necessarily represent the views of the U.S. Census Bureau. All results have been reviewed to ensure that no confidential information is disclosed. We thank John Abowd, Les Boden, Hank Farber, Lucia Foster, Martin Ganco, Steve Hipple, Hubert Janicki, David Neumark, Shu Lin Wee, participants at the U.S. Census Bureau research lunch, the University of Illinois Labor and Employment Relations School seminar, the Federal Reserve Bank of Kansas City CADRE workshop, the Midwest Economics Association annual meeting, the SoLE-EALE conference, the editor Rafeal Lalive, and an anonymous referee for helpful comments and suggestions.
} 


\section{Introduction}

Hire and separation rates in the U.S. have exhibited strong declines since the year 2000. It is natural to think that these declines would be associated with shifts in the job tenure of the workforce: the tenure distribution should shift toward longer tenure jobs when the inflow of new employees decreases, or when experienced workers stay at their jobs longer. Indeed, since the year 2000, the job tenure supplements to the Current Population Survey (CPS), whose aggregates are published by the Bureau of Labor Statistics, show that the job tenure distribution has shifted away from jobs that have been held for a short duration toward jobs that have been held for a longer duration. ${ }^{1}$ While there is ample evidence that the labor market is shifting toward more stable jobs, the causes and consequences of declining dynamics and increasing stability remain unknown.

In this paper, we consider how the shifting job tenure distribution helps us understand the causes and consequences of declining dynamics. We document the post-2000 shift in the job tenure distribution and compare this with trends in previous decades. With the aid of Longitudinal Employer-Household Dynamics (LEHD) matched employer-employee data, we confirm the shift in the job tenure distribution apparent in the CPS job tenure supplements. We explore the role that compositional changes in the U.S. labor market, especially the ageing of the workforce, have on the job tenure distribution. We use LEHD data to distinguish between the role of the hiring rate and the tenure-specific separation rates in the recent evolution of the job tenure distribution. We also consider the relationship between job tenure and earnings to see whether shifts in the job tenure distribution led to earnings increases, as well as whether there is evidence of improved match quality as a factor in shifting job tenure.

We begin with an overview of the job tenure distribution as given by the CPS job tenure supplements for the years 1951-2014. We document that the distribution of job tenure has shifted toward longer tenure jobs during the past decade and a half, which is consistent with the implications of declining hire and separation rates. According to published statistics from the

\footnotetext{
${ }^{1}$ This shift toward longer tenure jobs can be seen in, for example, Copeland (2015), the latest of a series published by EBRI Notes, which is updated after each biennial CPS job tenure supplement.
} 
Current Population Survey (CPS), the proportion of workers with five or more years of tenure on their main job has increased from 44\% to 51\% from 1998 to 2014, and the proportion of workers with one year or less of tenure on their main job has decreased from $28 \%$ to $21 \%$. We document a similar shift in the job tenure distribution for the years 1998 to 2013 using LEHD microdata, which is nearly identical to the CPS tenure distribution once differences between these source data are accounted for. We conduct a decomposition exercise that illustrates that a substantial amount of these changes in the job tenure distribution toward longer tenure jobs can be accounted for by changes in the labor market, especially the ageing of the workforce and the decline in new employer businesses.

To make progress on understanding declining dynamics in light of the changing job tenure distribution, we turn to hire and separation rates. We conduct an exercise that follows Neumark, Polsky, and Hansen (1999), who demonstrated that the tenure distribution can be created from aggregate hires and tenure-specific separations rates. It is straightforward to do this using the LEHD microdata, since it is universe-level longitudinal administrative data. Expressing the tenure distribution as a function of these macroeconomic aggregates, rather than building the distribution from the microdata, enables us to determine how the shifting tenure distribution is driven by time series movements in the aggregate hires and tenure-specific separation rates. Our results show that the shifting tenure distribution is due more to declines in the hiring rate rather than declines in tenure-specific separation rates. This is consistent with the shift in the tenure distribution being driven by lower hiring during and after the labor market downturns associated with the 2001 and 2007-2009 recessions.

We then turn to an analysis of the relationship between the shifting tenure distribution and earnings growth. Because earnings are increasing in job tenure, the shift in the job tenure distribution will lead to an increase in aggregate earnings. We evaluate this using both LEHD and CPS data. We see the effects of the shifting tenure distribution in the time series of real earnings, but we find that the small increase in real earnings in the U.S. economy since 2007 is less than what would be predicted by the shifting tenure distribution. This difference results from an earnings series which holds the tenure distribution constant declining during the 2007-2009 recession with little growth following the recession. We also explore the evolution of starting 
earnings and the returns to tenure over the last decade and a half. The data shows that the sum of starting earnings and the returns to tenure has been trending downward since at least 2004, which suggests that the shift in the job tenure distribution is not being driven by better matches for which the workers are compensated.

Our evaluation of the shifting job tenure distribution provides evidence on the causes and consequences of lower employment dynamics that the U.S. labor market has exhibited since the turn of the century. A number of recent papers have confirmed that reallocation rates in the labor market have declined from the late 1990s to the early 2010s. Hyatt and Spletzer (2013) and Davis and Haltiwanger (2014) document declines in hire and separation rates, job creation, job destruction, and job-to-job flows since the year 2000. Decker et al. (2014a, 2014b) document a long-term trend decline in the rate of new employer business entry that has accelerated since the year 2000. While it is well-known that employment reallocation rates are procyclical, the literature is just beginning to examine the consequences of declining employment dynamics on key labor market trends such as employment, earnings, and productivity. ${ }^{2}$ Early efforts to link these phenomena include Davis and Haltiwanger (2014), who estimate the relationship between employment reallocation and employment, and Faberman and Justiniano (2015), who consider the correlation between quits, earnings, and inflation.

Our composition analysis largely confirms findings from previous studies, such as Hyatt and Spletzer (2013) and Decker et al. (2014a), which found that the ageing workforce and declining entrepreneurship lead to declines in employment reallocation rates and so lead to lengthening job tenure. Also consistent with these studies, we find that the changing industry composition had an offsetting effect. One notable difference is that we find more explanatory power for the ageing of the workforce when considering broad tenure categories than previous studies that considered transition rates alone, and this is especially apparent in our composition analysis of the CPS.

\footnotetext{
${ }^{2}$ Policymakers believe that these declines may be important, as evidenced by the Federal Reserve taking note of these declines as a possible measure of slack in the labor market; see Yellen (2014).
} 
Our finding that the cyclical shifts in the job tenure distribution are more the result of declining hires provides an additional reference point for thinking about cyclical downturns. It is well-known that during and after economic contractions, quits fall, see Davis, Faberman, and Haltiwanger (2012), as do job-to-job transitions, see Hyatt and McEntarfer (2012b) and Hyatt and Spletzer (2013), and job-to-job transitions involve a hire and separation and are driven by voluntary quits, see Hyatt et al. (2014). While voluntary quits for new jobs certainly account for much of the close relationship between hires and separations, our analysis highlights the fact that there is substantial duration dependence in employment relationships: new jobs are the ones most likely to end. We find, furthermore, that the duration dependence of job spells (measured by tenure-specific separation rates) is not very cyclical compared with the cyclicality of hiring. This finding may be helpful in understanding the cyclicality of hires and separations not related to job-to-job transitions, as well as short duration jobs as considered by Hyatt and Spletzer (2013, 2015). If a substantial fraction of new jobs are very likely to end quickly, then declining hiring may remove separations for a reason other than job-to-job quits alone.

Our evaluation of the relationship between employment reallocation, the job tenure distribution, and earnings helps shed light on a relationship that is in principle ambiguous. There are reasons to believe that lengthening job tenure may be associated with earnings increases. Declining hire and separation rates will shift the tenure distribution to the right, and this shifting tenure distribution should increase the trend of real earnings (since earnings increase with tenure). Hyatt and Spletzer (2013) speculate that declining hires and separations may be indicative of better matching between employers and employees, which could be reflected in higher initial wages or steeper wage-tenure profiles. On the other hand, increasing job stability may be associated with lower earnings. Earnings increases from job change, highlighted by Topel and Ward (1992), may facilitate efficiency-enhancing employment reallocation, as in Jovanovic and Moffitt (1990). There are also indirect mechanisms through which a decline in employment reallocation may lead to lower earnings. As mentioned by Molloy, Smith, and Wozniak (2014), the decline in hires and separations may reflect fewer job offers from different employers, which will reduce the bargaining power of workers and reduce earnings. We find that earnings growth post-2000 was especially weak after controlling for job tenure, and we find no evidence of increased starting earnings or steeper earnings-tenure profiles: such findings are not 
consistent with improved job match quality. The modest declines in tenure-adjusted earnings post-2000 that we find are more likely evidence of weaker labor demand, less efficiency enhancing reallocation, or some combination of the two.

This paper proceeds as follows. The following section describes the time trend in the job tenure distribution from the CPS 1951-2014. In Section III, we describe the job tenure distribution in the LEHD data 1998-2013. In Section IV, we conduct an analysis to distinguish the roles of the hiring rate relative to the tenure-specific separation rates. In Section V, we analyze the relationship between job tenure and earnings over time. A brief conclusion follows.

\section{The Shifting Tenure Distribution in the Current Population Survey}

The Current Population Survey (CPS) is the workhorse dataset of labor economics. In addition to continually collecting data on employment, unemployment, and earnings, the CPS occasionally administers supplements which inquire about various labor market topics such as job tenure. The job tenure supplements ask about how long currently employed respondents have held their main job. This supplement has been conducted every two years since 1996, and tenure data is also available for selected earlier years. ${ }^{3}$

Median tenure and select statistics from the tenure distribution since 1951 are shown in Figure $1{ }^{4}$ To facilitate comparisons across time, and for tractability, we aggregate the CPS tenure categories into three groups: one year or less, more than one but less than five years, and five years or more. In addition, we present two other series: six months or less and ten years or more. Median job tenure, shown in the top panel of Figure 1, has been between 3.4 and 3.9 years

\footnotetext{
${ }^{3}$ We use data from 1951, 1963, 1966, 1968, 1973, 1978, 1981, 1983, 1987, 1991, 1996, and then every two years thereafter: 1998, 2000, etc. to 2014. The microdata for the early supplements have been lost, see Farber (1999), but tabulations are available in historical issues of the Monthly Labor Review.

${ }^{4}$ We acknowledge that there are differences in the CPS tenure data across time that we gloss over when presenting the time series in Figure 1. For example, although the questions are identical in the 1996 through 2014 surveys, the 1996, 1998, and 2000 surveys were conducted in February whereas the 2002 through 2014 surveys were conducted in January (which could matter if the population of employed is different in the two months). Furthermore, the questions, the response categories, and the tabulation methodologies have changed across time. Of particular note is the 1951 survey, which records whether the current job started during the four periods of prior to World War II, during World War II, after World War II but before the start of the Korean War, or after the start of the Korean War, corresponding roughly to ten years or more, five to nine years, more than six months but less than five years, and six months or less, respectively.
} 
during the 1968 to 2002 time period, with the exception of 3.2 years in 1981. The increase in median tenure since 2000 stands out, rising from 3.5 years in 2000 to 4.6 years in 2012 and 2014. This recent increase in median job tenure is evident when looking at the tenure distribution in the bottom panel of Figure 1. The percent of the employed with five or more years of tenure averaged 43\% from the mid-1960s to 2000, and has risen to about 51\% in the 2012 and 2014 surveys. ${ }^{5}$ The percent of the employed with one year or less of tenure averaged $27.5 \%$ from the mid-1960s to 2000, whereupon it fell to just over 21\% in 2012 and 2014 (and falling below 20\% for the first time ever in 2010). The percent of employed workers with 10 or more years is basically flat at around 26\% during the 1983-2006 time period, followed by an increase from 25.4\% in 2006 to just over 29\% in 2012 and 2014.

The CPS evidence shows several striking patterns. First, job tenure appears to be at an all-time high in the early 1960s, as the 1963 job tenure supplement shows an extraordinarily high percentage of workers, 35.5\%, with more than ten years of tenure at their current job. The mechanism by which the share changed from $22.5 \%$ in 1951 to $35.5 \%$ in 1963 is difficult to evaluate, as the underlying survey responses for both supplements has been lost, and there is no other data that we are aware of on job tenure during the 1950s or early 1960s. Nevertheless, there was a gradual decline in the share of jobs held for long durations, which stabilized by the late 1970s. ${ }^{6}$ The job tenure distribution is then stable until the late 1990s, after which the job tenure distribution shifts toward longer tenure jobs again. The shift toward longer-tenure jobs is the most dramatic since the 1950s, when the U.S. labor market was continuing to adjust after the end of the World War II and the entry of those formerly in the military into the civilian labor market. We also note that, in the 2000 supplement and afterwards, the share of jobs held for one year or less, which is a rough proxy for the hiring rate, has a similar "stair step” pattern to what Hyatt and Spletzer (2013) observe for hires more generally, with declines during the labor market

\footnotetext{
${ }^{5}$ Careful readers will note that in the two most recent job tenure supplements, the median job tenure is below five years while the share of jobs five years or more is in excess of 50\%. This seeming discrepancy is because the BLS calculates interpolated medians, which assumes that job tenure is uniformly distributed within intervals centered on whole numbers.

${ }^{6}$ The CPS is only one data source on job tenure, and in the late 1960s additional data sources become available. Stevens (2005), using the Retirement History Survey, the National Longitudinal Survey of Older Men, and the Health and Retirement Study, does not find anything exceptional about the job tenure of older men in 1969 relative to 2002.
} 
downturns associated with the 2001 and 2007-2009 recessions and comparatively small recoveries afterwards.

Some readers will recall that there was much discussion in the late 1990s about whether job stability had declined during the 1980s and 1990s, and whether, in the early part of the new millennium it would continue to decline. Studies using the Panel Study of Income Dynamics and the CPS found declining tenure for older men when looking at the 1980s and early 1990s. In the published CPS data, there is a dramatic change in the share of employed men over the age of 45 who had held their jobs for ten years or more: in 1983, 61.4\% of employed men had held their jobs for ten years or more, while in 1998, only 51.0\% had held their jobs for that long. As Neumark, Polsky, and Hansen (1999) note, concerns about declining stability are consistent with the corporate downsizing that occurred during this time, and with the notion of fewer lifetime jobs that was picked up by the popular press. However, the studies by Jaeger and Stevens (1999), Neumark, Polsky, and Hansen (1999) and Farber (1999) showed that job stability did not show any strong trend from the 1980s to the 1990s. Indeed, in the CPS published data, the share of the total workforce that had held their jobs for 10 years or more increased from $25.2 \%$ to $25.8 \%$ between 1983 and 1998. As noted more recently by Farber (2008) and Hollister and Smith (2014), any losses among men were basically offset by gains in job tenure among women, whose share of employment was also rising during this time period.

We note that any declines in job stability are features of the 1980s and early 1990s, and that the more recent data looks very different. Between 1998 and 2014, any declines in job stability that occurred during the 1980s and 1990s either stabilized or reversed, which is also true by age and gender. ${ }^{7}$ While there was no recovery in the share of employed men age 45 or above who had held their jobs ten years or more, it did not substantially decline, and stood at $51.0 \%$ in 1998 and 50.9\% in 2014. The corresponding share of the total workforce that held their jobs for ten years or more increased from $25.8 \%$ to $29.1 \%$. What is more striking is an across-the-board fall in the share of the employed who had been at their jobs for one year or less, which declined from $27.8 \%$ in 1998 to $21.3 \%$ in 2014 , and the magnitude of the decline is only slightly larger

\footnotetext{
${ }^{7}$ Percentages referenced in this paragraph, as well as other detailed statistics on the job tenure distribution by age and gender for 1983-2014, are included in the Appendix.
} 
among women than men. This decline is basically balanced by an opposite shift in the share of the employed who had been at their jobs for five years or more, which can also be seen in Figure 1. We find it striking that economists have given so little attention to the strong rightward shift in the tenure distribution that has occurred during the last 15 years.

The descriptive evidence we have presented using the published totals and shares that the BLS calculates from the CPS job tenure supplements provides rough evidence on the evolution of the job tenure distribution. We will demonstrate that this evolution is related to the declines in the hire and separation rates documented by Hyatt and Spletzer (2013) and Davis and Haltiwanger (2014). This is intuitively straightforward. When hires fall, the tenure distribution should shift to the right as the inflow of new employees into a firm decrease. The decrease in separations should also shift the tenure distribution to the right as the outflow of current employees from a firm decrease. In order to consider this relationship between hires, separations, and tenure in greater detail, we turn to longitudinal microdata from the LEHD.

\section{Job Tenure in the LEHD Data}

\section{IIIa. The LEHD Data}

The Longitudinal Employer-Household Dynamics (LEHD) data is a longitudinally linked employer-employee dataset created by the U.S. Census Bureau as part of the Local Employment Dynamics federal-state partnership. The data is derived from state-submitted Unemployment Insurance wage records and the Quarterly Census of Employment and Wages (QCEW) data. Every quarter, employers who are subject to state Unemployment Insurance laws -approximately $98 \%$ of all private sector employers, plus state and local governments -- submit to the states information on their workers (the wage records, which lists the quarterly earnings of every individual in the firm) and their workplaces (the QCEW, which provides information on the industry and location of each establishment). The wage records and the QCEW data submitted by the states to the U.S. Census Bureau are enhanced with census and survey microdata in order to incorporate information about worker demographics (age, gender, race and ethnicity, and education) and the firm (firm age and firm size). 
Abowd et al. (2009) provide a thorough description of the source data and the methodology underlying the LEHD data. Because states have joined the LEHD program at different times, and have provided various amounts of historical data upon joining the LEHD program, the length of the time series of LEHD data varies by state. We use 10 states with data from 1993:Q1-2013:Q4, which account for roughly 28\% of U.S. employment. ${ }^{8}$ In order to ensure accurate measures of job tenure that are not affected by mergers, acquisitions, or other types of firm ownership change (or administrative changes in firm identifiers), all of our empirical work uses an enhanced version of the LEHD that identifies predecessor-successor relationships across extended periods of time; see Hyatt et.al (2014) for additional details of some recent enhancements to the LEHD data.

Since the LEHD is essentially a universe of workers in the private sector and state and local governments, sample size is not an issue when choosing the 10 states from which we have data starting in 1993. We define the maximum tenure category of $5+$ years, and thus our time series of tenure starts in 1998. We want to start our tenure series in 1998 because the CPS indicates that the inflection point in the job tenure distribution occurs around 2000, and it is precisely this change that we intend to capture. We can then identify job tenure from 1998 to 2013.

In calculating a consistently defined time series of job tenure from administrative records, there are natural tradeoffs between the length of the time series and maximum tenure. This tradeoff exists because the data do not contain start dates, we instead can only infer job tenure by observing earnings in successive quarters. Any earnings observed in the first quarter for which administrative records are present are necessarily left-censored, and the exact tenure is unknown. However, if that job exists for a given number of quarters after the first quarter, it is known to have existed for at least that length. We start our time series in 1998 to have a consistently defined set of jobs for which it can be known that employment had lasted five years or more. For

\footnotetext{
${ }^{8}$ The 10 states are CA, CO, ID, IL, MD, MT, NC, OR, WA, and WI. The published hire and separation rates from these 10 states are strongly correlated with national trends as estimated by Abowd and Vilhuber (2011).
} 
example, if we start our time series one year earlier, we would have had to reduce the duration of our maximum tenure category by one year.

IIIb. The Job Tenure Distribution in the LEHD Data

We define concepts precisely as they follow from tabulations of the data. The definitions follow from Abowd et al. (2009) and Hyatt and Spletzer (2014). A job is defined as a unique employer-employee combination that occurs in one or more consecutive quarters. ${ }^{9} \mathrm{~A}$ hire can be written as a case in which a worker has earnings recorded at a given employer in a quarter, but not in the previous quarter. So, for worker $i$, firm $j$, and time $t$, a hire (accession) is defined by

$$
a_{i j t}=\left\{\begin{array}{l}
1, \text { if } w_{i j t}>0, w_{i j t-1}=0 \\
0, \text { otherwise }
\end{array}\right.
$$

Likewise, at time $t$, a separation is given by the following definition,

$$
s_{i j t}=\left\{\begin{array}{l}
1, \text { if } w_{i j t+1}=0, w_{i j t}>0 \\
0, \text { otherwise }
\end{array} .\right.
$$

More generally, at time $t$, a job has tenure (duration $d$ ) $k$ if

$$
d_{i j t}^{k}=\left\{\begin{array}{l}
1, a_{i j t-k}=1 \text { and } w_{i j \tau}>0 \text { for all } \tau=\{t-k, \ldots, t\} \\
0, \text { otherwise }
\end{array}\right.
$$

Tenure is defined as the number of previous quarters with the employer, with hires occurring at $k=0$. Starting tenure at $k=0$ is similar to the concept of human age, where newborns have an age of zero during their first year. In our empirical work with the quarterly LEHD data, we identify the tenure of each job for up to five years, with jobs lasting for 5 years or more indexed by $k=19+$.

\footnotetext{
${ }^{9}$ For our baseline LEHD job tenure distribution, we consider recalls to be new jobs. We also have a "modified LEHD” series which ignores recalls, in addition to other changes, as described in section IIIc.
} 
Given these definitions, we can derive a tenure distribution from the LEHD microdata. In Figure 2, we show the tenure distribution calculated from the LEHD data. Similar to the CPS data in the bottom panel of Figure 1, three tenure categories are created from the LEHD data: one year or less, greater than one but less than five years, and five or more years. Long-tenure jobs in the LEHD trend upward since 2000, with the share of jobs that have been held for five years or more increasing from an average 21.4\% in the year 2000 to an average 32.4\% in 2012 and 2013. Likewise, the number of jobs with tenure of one year or less trend downward, with the declines coming during the two recessions, declining from $46.8 \%$ in the year 2000 to $35.8 \%$ in the years 2011-2013. The number of jobs held for greater than one but less than five years increases and subsides as sudden drops in the share of jobs held for one year or less work their way into the share of jobs held for five years or more, but does not otherwise show much of a trend.

Overall, the trends of the LEHD tenure distribution shown in Figure 2 are remarkably similar to the trend of the CPS tenure distribution shown in Figure 1. The correlation between the two series is 0.98 for the one year or less category, is 0.94 for the greater than one but less than five year category, and is 0.96 for the five years or more category. It is also immediately obvious that the CPS and the LEHD tenure distributions have different levels for each category. The CPS tenure distribution in Figure 1 has a much larger share of jobs held for five years of more - e.g. at the start of the year 2012 it is $51.0 \%$ in the CPS versus $35.6 \%$ in the LEHD.

\section{IIIc. Comparing the CPS and the LEHD Job Tenure Distributions}

Considering how the CPS and LEHD data sources differ in the concepts and definitions used to measure tenure, it should not be surprising that the levels of the CPS and LEHD tenure distributions differ. The LEHD is a jobs-level dataset, in contrast to the person-level CPS data. The CPS asks respondents about the tenure at the respondent's main job only, while the LEHD data measures tenure at all jobs so long as they are in Unemployment Insurance taxable employment. Since secondary jobs are, on average, of shorter duration than primary jobs, this will help explain why the LEHD has more short duration jobs than does the CPS. Second, the CPS is a point-in-time measure of the tenure distribution while the LEHD utilizes quarterly earnings data. This means that the LEHD data will contain more records for short duration jobs 
than the CPS data since many short duration jobs - jobs that last only one or two weeks - will not occur during the CPS reference week. ${ }^{10}$ Third, tenure in the LEHD as defined above is "memoryless" in that if a worker has no reported earnings from an employer for an entire quarter, tenure is reset to zero if that worker returns to the employer after one or several quarters. Recent work by Fujita and Moscarini (2013) demonstrates that recalls are quantitatively important in the Survey of Income and Program Participation (SIPP) data. Accounting for recalls changes the shape of the LEHD tenure distribution: using the first observed occurrence of a job rather than the date of the most recent hire naturally results in longer job durations. Fourth, the LEHD excludes federal workers, who tend to have longer job tenure than workers in the private sector.

We control for each of these four differences in order to create an "apples-to-apples" comparison of the tenure distributions from the CPS and the LEHD data. ${ }^{11}$ Specifically, we restrict the LEHD data to jobs that appear in two consecutive quarters to minimize the effects of short duration jobs, we restrict the LEHD data to dominant jobs only (where dominant jobs are defined as the highest earnings job in the two quarters of the consecutive quarter pair, see Hyatt et al. (2014)), thus removing the effect of multiple jobholding, and we allow for five years of “memory" to account for recalls. To create the "modified CPS," we remove federal government employees.

The result of this apples-to-apples comparison of the modified CPS tenure distribution and the modified LEHD tenure distribution is presented in Figure 3. The two distributions are remarkably similar (much more similar than the original data in Figures 1 and 2), and this similarity holds for both levels and trends. Almost all of this similarity results from our manipulations of the LEHD data; only $2.8 \%$ of employment in any average year of the CPS is federal government employees, and removing these workers has little effect on the CPS tenure distribution. The average percentage of jobs with five years or more of tenure increases from

\footnotetext{
${ }^{10}$ Administrative data show a remarkably large number of short duration jobs. Hyatt and Spletzer (2015) analyze the decline in single quarters jobs - jobs that last less than 13 weeks - from $8.3 \%$ in the late 1990 s to $5.2 \%$ in the early 2010s as a share of total quarterly employer-employee observations.

${ }^{11}$ Two other differences that we do not control for are (1) the LEHD data include all jobs regardless of the age of the individual holding the job, while the CPS tenure supplements are for the workforce age 16 and above, and (2) the LEHD estimates are seasonally adjusted quarterly estimates, whereas the CPS are non-seasonally adjusted estimates from the month of January or February.
} 
$32.4 \%$ in recent years of the jobs-based LEHD (Figure 2) to almost 50\% when deleting short duration jobs, multiple jobs, and controlling for recalls (Figure 3). Of our three modifications to the LEHD, selecting consecutive quarter jobs substantially reduces the number of jobs held for one year or less, while ignoring gaps in a job spell mainly affects the share of jobs held for five years or more, and focusing on the job that is dominant among those consecutive quarter jobs has a relatively modest effect.

\section{IIId. Does Changing Composition Explain the Shifting Tenure Distribution}

Can compositional changes in worker and employer characteristics during the last one and a half decades explain some or all of the shifting tenure distribution? For example, the baby boom has aged and youth labor force participation has declined during the past decade and a half, which should lead to a rightward shift in the tenure distribution since older workers have, on average, higher job tenure. We measure the effect of composition changes using standard decomposition techniques. Let $Y_{t}$ be the percentage of jobs with five or more years of tenure in time period $t . Y_{t}$ can be written as $\sum_{i} Y_{i t} S_{i t}$, where $i$ indexes characteristics of worker or firms (such as worker age or industry), and $S_{i t}$ is the share of group $i$ at time $t$. We decompose the difference between times $t$ and $t-x, \Delta Y_{t}=Y_{t}-Y_{t-x}$, according to

$$
\Delta Y_{t}=\sum_{i} \Delta Y_{i t} S_{i} \cdot+\sum_{i} Y_{i} \cdot \Delta S_{i t}
$$

where $Y_{i}$. denotes the mean such that $Y_{i}=\left(Y_{i t}+Y_{i t-x}\right) / 2$, and likewise $S_{i \cdot}=\left(S_{i t}+S_{i t-x}\right) / 2$. In Table 1, we report $\sum_{i} Y_{i} \cdot \Delta S_{i t} / \Delta Y_{t}$, which measures how much of the increase in jobs with five or more years of tenure over the time period 1998 to 2012 is due to the changing composition of characteristic $i$.

The results of these decompositions are similar to, but sometimes larger in magnitude than, the findings of Hyatt and Spletzer (2013) and Decker et al. (2014), who found that the ageing of the workforce and declining entrepreneurship explained a substantial fraction of the decline in employment reallocation rates, and that industry had a substantial offsetting (negative) effect. In Table 1, worker age explains the largest amount of the shifting tenure distribution. 
Using the CPS data, worker age explains just over half of the increase in the percent of jobs with five or more years of tenure, while in the LEHD it explains 25.4\% for all LEHD jobs, and somewhat more, 30.7\%, for the LEHD series modified to cover similar concepts and definitions as the CPS job tenure supplement. ${ }^{12}$ We note that the explanatory power of the ageing of the workforce is higher for explaining increasing share of the workforce that has been at their jobs for five years or more than for the transition rates that lead to that job tenure: Hyatt and Spletzer (2013) consider the explanatory power of the ageing of the workforce on hires, separations, and job-to-job flows in both the LEHD and CPS using a nearly identical time period and exactly the same age categories, and never find that the ageing of the workforce explains more than $25 \%$ of declining employment dynamics.

Factors other than the ageing of the workforce have less explanatory power and are more in line with the magnitude of previous estimates. Increasing education explains $2.6 \%$ of the increase in the percentage of workers with five years or more of tenure in the CPS. The changes in industry composition show a negative effect, which is explained by the economy shifting away from manufacturing, where there are many high tenure jobs, to services where there are relatively few high tenure jobs. The LEHD data allow us to consider the effects of the changing firm size and firm age (time from first hire) distribution toward larger and older firms. ${ }^{13}$ Firm size has a small explanatory role, whereas firm age explains $14 \%$ to $18 \%$ of the shift in the job tenure distribution. Firm age has the second highest explanatory power in the decomposition. When we account for all worker and employer characteristics, we explain $37 \%$ to $38 \%$ of the

\footnotetext{
${ }^{12}$ The amount of the increase in job tenure attributable to age in Table 1 depends on the beginning and end years of the decomposition. The LEHD data yield age composition results that are in the range of $18.2 \%$ to $38.0 \%$ using 1998-2001 as start years and 2010-2013 as end years. The CPS age decomposition results are in a narrow range of $46.0 \%$ to $56.6 \%$ when using 1998 or 2000 as the base year and 2012 or 2014 as the end year. As seen in Figure 1, the share of workers with five or more years of tenure in the CPS declined between 1996 and 1998 (both expansion years), and the 1996 share was not reached again until 2004, and so we naturally get smaller long-tenure share increases and more explanatory power when using 1996 as our start year. Similarly, the share of long-tenure workers is lower in 2010 than in 2012 and 2014, which leads to smaller increases and more explanatory power when using 2010 as the end year in the CPS. Overall, this sensitivity analysis points to the role of business cycles in the shifting job tenure distribution, which we engage with more directly in later sections of this paper. We thank an anonymous referee for this suggestion.

${ }^{13}$ Between 2000 and 2010, the share of workers at small firms with less than 20 employees declined by 2.1\% (from $22.9 \%$ to $20.8 \%$ ) while the share of workers at large firms with 500 or more employees increased by $2.4 \%$ (from $47.2 \%$ to $49.6 \%$ ). The firm age distribution has changed between 2000 and 2010, with the share of employment at firms 1 year old or less declining from 5.2\% to 3.5\%, and the share of employment at firms 11 years or older increasing from $74.4 \%$ to $78.7 \%$. The decline in firm entry has been explored by, among others, Decker et al. (2014a), Pugsley and Sahin (2015), Siemer (2015), and Dinlersoz, Hyatt, and Janicki (2016).
} 
increase in jobs with five or more years of tenure in the CPS, and $42 \%$ to $50 \%$ in the LEHD. This implies that half or more of the shifting tenure distribution is occurring within narrowly defined demographic and employer characteristic cells from 1998-2012.

We have shown that the shift in the tenure distribution toward longer-tenure jobs over the last decade and a half can be accounted for in part due to the rising share of older employees and the decline in the rate of entry of new employer businesses. These are in part demographic stories, but are also partly economic. While the U.S. population was certainly ageing from the late 1990s to the present, the labor market downturns associated with the 2001 and 2007-2009 recessions disproportionately affected the employment rates of the young. Recent declines in employer business entry are concentrated in and after the 2001 and 2007-2009 recessions, see Decker et al. (2014a). In the following sections, we focus on causes and consequences of the shifting job tenure distribution that highlight these two labor market downturns more directly.

\section{Hires, Separations, and the Shifting Job Tenure Distribution}

\section{IVa. Concepts}

Hires and separations have a natural relationship with job tenure as each job spell begins with a hire and ends with a separation. We frame this relationship through a simple model of the evolution of tenure in the spirit of Neumark, Polsky, and Hansen (1999). At time $t$, the tenure $k$ indicator, $d_{i j t}^{k}$, can be written as the product of the hires indicator in the appropriate previous time period times the tenure-specific separation indicators for each time thereafter:

$$
d_{i j t}^{k}=a_{i j t-k} * \prod_{\tau=1}^{k}\left(1-s_{i j t-\tau}^{k-\tau}\right)
$$

where the tenure-specific separations indicator, $s_{i j t-\tau}^{k-\tau}$, is defined as

(5) $\quad s_{i j t-\tau}^{k-\tau}=\left\{\begin{array}{l}1, \text { if } s_{i j t-\tau}=1 \text { and } d_{i j t-\tau}^{k-\tau}=1 \\ 0, \text { otherwise }\end{array}\right.$ 
Equation (4) defines tenure $k$ for a specific job in the longitudinally linked microdata, and the distribution of tenure in a given quarter $t$ can be defined by summing over all jobs in that quarter. However, it is often more convenient to work with macro-level tabulations, and to transform the above formula into rates. Define the size of the workforce at time $t$ as $E_{t}$. The percent of jobs at time $t$ of tenure $k, D R_{t}^{k} \equiv \frac{\sum_{i, j} d_{i, j, t}^{k}}{E_{t}}$, can now be written as the size of the workforce and two rates: the hiring rate $A R_{t-k} \equiv \frac{\sum_{i, j} a_{i, j, t-k}}{E_{t-k}}$, and the tenure-specific separation rates $S R_{t-\tau}^{k-\tau} \equiv \frac{\sum_{i, j} s_{i, j, t-\tau} d_{i j t-\tau}^{k-\tau}}{\sum_{i, j} d_{i j t-\tau}^{k-\tau}}$ :

$$
D R_{t}^{k}=\left(\frac{E_{t-k}}{E_{t}}\right) * A R_{t-k} * \prod_{\tau=1}^{k-1}\left(1-S R_{t-\tau}^{k-\tau}\right)
$$

Equation (6) shows the decomposition of the tenure distribution into its hiring and separation components. Using the same three tenure categories as earlier (one year or less, greater than one but less than five years, and five or more years), the hires rate is, by definition, the percent of jobs that are in their first year of tenure. As seen in Figure 2, this hiring rate falls from around $46 \%$ in the late 1990s to roughly 35\% in the early 2010s, and this decline exhibits a stair-step pattern, falling during recessions with very little evidence of an increase during expansions. The tenure-specific separation rates for the three tenure categories are shown in Figure 4. There are noticeable trend declines in each of the tenure-specific separation rates, but they are remarkably acyclical. The highest separation rates are, not surprisingly, found for the shortest duration jobs; the separation rate from jobs with one year or less of tenure declines from $34.2 \%$ in the late 1990 s to $29.7 \%$ in the 2010 s. Jobs held for greater than one but less than five years have a separation rate that decreases from $12.3 \%$ in the late 1990 s to $9.8 \%$ in the 2010 s, while workers who have held their jobs for five years or more have a separation rate that falls from $5.5 \%$ to $4.0 \%$. Overall, these decreases are much smaller than those seen in the hiring rate.

\section{$I V b$. The Role of Hires versus Separations Rates}

One advantage of creating the tenure distribution from macroeconomic aggregates, as in equation (6) above, rather than from the microdata, is that it easily allows us to analyze the 
driving forces of the shifting tenure distribution. We adopt an approach similar to Shimer (2012), where we set all but one of the macroeconomic aggregates in equation (6) to their long-run average, and create the time series of tenure where only one of the aggregates is allow to vary. ${ }^{14}$

To be specific, we compute two counterfactual tenure distributions based on equation (6): one where the tenure-specific separation rates are fixed at their long run sample average, $\overline{S R}^{k-\tau}$, and one where the hiring rate is fixed at its long run sample average, $\overline{A R}$ :

$$
\begin{aligned}
& D R_{t}^{k}=\left(\frac{E_{t-k}}{E_{t}}\right) * A R_{t-k} * \prod_{\tau=1}^{k-1}\left(1-\overline{S R}^{k-\tau}\right) \\
& D R_{t}^{k}=\left(\frac{E_{t-k}}{E_{t}}\right) * \overline{A R} * \prod_{\tau=1}^{k-1}\left(1-S R_{t-\tau}^{k-\tau}\right)
\end{aligned}
$$

These two counterfactual distributions, with employment shares across the tenure categories restricted to add to one, are graphed in Figure 5 (in grey), alongside the actual distribution (in black). The top panel holds the tenure-specific separation rates fixed and allows the hiring rate to vary over time, as in equation (7a), whereas the bottom panel holds the hiring rate fixed and allows the tenure-specific separation rates to vary over time, as in equation (7b). It is immediately obvious that the hiring rate is the key driving force underlying the shifting tenure distribution - the counterfactual distribution in the top panel of Figure 3 better replicates both the trend and the cyclicality of the data than does the counterfactual distribution in the bottom panel. Quantifying the trend, the counterfactuals in the top panel of Figure 5 explain 93 percent of the falling percentage of workers with 1 year or less of tenure and 117 percent of the increasing percentage of workers with 5 years or more of tenure, whereas the counterfactuals in the bottom panel of Figure 5 explain 47 and 35 percent respectively. ${ }^{15}$ Quantifying the cyclicality, the

\footnotetext{
${ }^{14}$ Another approach, which is similar to Elsby, Michaels, and Solon (2009), is to take natural logs of the both sides of equation (6) which then yields an additive time series decomposition. This approach is problematic here since our three tenure categories are sums of multiple quarters (for example, the percent with one year of less of tenure is the sum of four quarters of tenure), and the log of a sum does not yield a clean additive decomposition. Nevertheless, we have analyzed this natural log decomposition on specific quarters of tenure (one quarter, two quarters, etc.), and obtain conclusions that are consistent with the results described in the text.

${ }^{15}$ These quantifications are somewhat sensitive to whether we hold the hiring and separation rates at their long-run average or at initial 1998 levels, but we have concerns about using initial levels. Hiring and separation rates have fallen since the mid-to-late 1990s, which implies that these rates are at their highest in 1998, the initial year of our panel. Fixing separation rates at a high 1998 level while allowing hiring rates to vary (that is, fall over time) results
} 
correlations between the counterfactual series and the original data in the top panel are .97 for 1 year or less of tenure and .98 for 5 years or more of tenure, whereas the correlations are lower (.86 and .69, respectively) in the bottom panel.

It is noteworthy that the labor market downturns associated with the 2001 and 2007-2009 recessions are readily apparent in the counterfactual distributions in the top panel of Figure 5. The shifts in the hiring rate used in this exercise, the rate of entry into jobs of the lowest tenure category, has a "stair-step" evolution that appears to explain much of the shifts in the job tenure distribution. ${ }^{16}$ This exercise makes clear that, in these two most recent labor market downturns, the hiring rate has a strong relationship with the ultimate distribution of the job tenure distribution. It also suggests that the extent to which the hiring rate recovers to levels last seen in the 1990s will determine whether the job tenure distribution will ever return to the distribution it exhibited from the late 1970s to the late 1990s.

\section{The Implications of a Shifting Tenure Distribution for Earnings}

\section{Va. The Tenure Composition Effect}

The shifting tenure distribution has implications for the time series of earnings. We know that high tenure jobs earn more than low tenure jobs, due to reasons such as accumulation of firm-specific human capital, deferred compensation, or matching. The classic empirical studies in the literature are Abraham and Farber (1987), Altonji and Shakotko (1987), and Topel (1991).

in extremely large employment losses in our counterfactuals; this is because net employment growth is equal to hires minus separations. Similar reasoning holds if we were to fix hiring rates at their high 1998 level and allow separations to fall over time - here the counterfactual employment levels rise phenomenally. We believe that fixing the hiring rate and the tenure-specific separation rates at their long-run average is the empirically best way of creating counterfactual tenure distributions that do not result in large employment losses or gains over time. We do find that when using long-run averages, our results are not sensitive to whether we start the exercise at 1998 or 2000.

${ }^{16}$ Indeed, the counterfactual in the top panel of Figure 5 appears to explain "more than all" of the shift in the percent of the workforce with five or more years of tenure. It is tempting to try to compare the counterfactual results in Figure 5 to the decomposition results in Table 1. However, they are not comparable. The decompositions in Table 1 are exact statistical exercises where everything adds up and we can isolate the contribution of one specific explanatory characteristic. This is not true when creating the counterfactual distributions in Figure 5, since holding separations constant while allowing hires to fall (as in the top panel of Figure 5) implies employment is declining over time, which is a direct contradiction to the observed data and thus is not an exact statistical exercise. 
The interaction of a shifting tenure distribution with an upward sloping earnings-by-tenure profile will result in a composition effect that increases the level of aggregate average earnings.

We can easily compute a tenure-held-constant earnings series that will quantify this composition effect. Start by noting that average earnings in quarter $t, \bar{w}_{t}$, can be written as the weighted average of tenure specific average earnings in quarter $t, \bar{w}_{t}^{\text {tenure }}$ :

$$
\bar{w}_{t}=\sum_{\text {tenure }=0}^{19+} \bar{w}_{t}^{\text {tenure }} * S H A R E_{t}^{\text {tenure }}
$$

where $S H A R E_{t}^{\text {tenure }}$ is the percent of the employed in a specific tenure category in quarter $t$. A counterfactual earnings series that does not allow the tenure distribution to shift can be written as:

$$
\text { Tenure held constant } \bar{w}_{t}=\sum_{\text {tenure }=0}^{19+} \bar{w}_{t}^{\text {tenure }} * S H A R E_{2000}^{\text {tenure }}
$$

where the tenure distribution is held constant at its 2000’s value.

The LEHD earnings measure that we use is "full quarter earnings." In quarters when an individual starts a job or separates from a job, we do not know how long within the quarter the individual worked (there is no measure of weeks worked within the quarter). Full quarter earnings are defined as the earnings from the middle quarter when individuals work for the same employer for three consecutive quarters. Using full quarter earnings allows us to assume that the individual worked all 13 weeks during the quarter. Note that when using full quarter earnings, we have no earnings from the quarter when the individual was hired into the job. In what follows, we drop the modifier "full quarter" when referring to LEHD earnings.

The solid black line in Figure 6 presents the seasonally adjusted time series of real quarterly earnings from the LEHD, defined according to equation (8) above. We use the Consumer Price Index (CPI) to convert nominal values to real (for both LEHD and CPS earnings). We see that real earnings in the U.S. were rising by an annual rate of $2.4 \%$ during the 1999 to 2001 time period, and then stagnated during the early- and mid- 2000s, rising by an 
average annual rate of $0.5 \%$ during the 2002 to 2007 time period. There was an increase in earnings during the 2007-2009 recession, with most of this increase occurring in 2008:Q4 and 2009:Q1. Real earnings then fell by an average annual rate of 0.6\% in 2011 and 2012.

The counterfactual earnings series from equation (9a) is the dashed line in Figure 6 (the line always below the solid line). If tenure was held constant at its 2000 distribution (not allowing the tenure distribution to shift to the right), real earnings would have declined between the late 1990s through 2013. The time series pattern is interesting: the tenure-held-constant earnings series declines during and immediately after the 2001 recession, followed by a moderate increase in the mid 2000s. The tenure-held-constant earnings series declines dramatically during the 2007 through 2009 recessionary period, with no observed growth in the 2010 through 2013 time period. Since tenure-held-constant earnings have declined, we conclude that earnings growth from the early 2000s to the 2010s is considerably weak in light of the shifting job tenure distribution.

This conclusion is enhanced by looking at an earnings series that holds tenure-specific earnings constant over time. Specifically, we define this counterfactual earnings series as:

$$
\text { Earnings held constant } \bar{w}_{t}=\sum_{\text {tenure }=0}^{19+} \bar{w}_{2000}^{\text {tenure }} * S H A R E_{t}^{\text {tenure }}
$$

where tenure-specific average earnings is held constant at its 2000 levels. This counterfactual earnings series, which is the dotted line in Figure 6 (above the solid line), holds constant any cyclical and trend growth in tenure-specific average earnings in order to highlight how the shifting tenure distribution has affected real earnings during the past decade and a half. This series shows a stair-step pattern that mimics the pattern of low-tenure jobs in Figure 2: the series is rising through the 2001 recession and also through 2002, constant during much of the mid 2000s, and rising again sharply during the 2007-2009 recession, and is then essentially constant during the 2010s. The 2012 and 2013 values of this counterfactual earnings series exceed the actual observed values of earnings by roughly $\$ 470$, which is the predicted effect of the shifting tenure distribution if tenure-specific average earnings had not fallen during the 2007-2009 recession. 
This exercise of computing counterfactual earnings series sheds light on the evolution of real earnings during the last 15 years. During the last two recessions, the growth in real earnings is the result of two opposite effects - increasing real earnings due to the composition effect from the shifting tenure distribution (which is due largely to a declining hiring rate), and decreasing tenure-specific average real earnings. The moderate growth in real earnings from 2003 to 2006 is accounted for entirely by an increase in tenure-specific average earnings which occurred in the context of an economic expansion. The stagnation of real earnings following the 2007-2009 recession reflects simultaneous stagnation of tenure-specific real earnings and a lack of movement in the tenure distribution.

\section{Vb. The Composition Effect in CPS Data}

The tenure and earnings data from the LEHD lead us to conclude that all real earnings growth from the late 1990s through the early 2010s is due to the shifting tenure distribution. Do we also see this using the CPS data? In this section, we use the CPS earnings data from individuals who are in the outgoing rotation groups in the months that the tenure supplements were asked. The empirical results that follow are not as easy to interpret as the LEHD results because we have earnings data that are from either January or February supplements that are two years apart, rather than quarterly as in the LEHD. ${ }^{17}$

The biennial real weekly earnings series and the two counterfactual earnings series from the CPS data are presented in Figure 7. The solid black line is observed earnings computed directly from the data. We see rising real earnings during the 1990s and stagnating real earnings during the long time period of the 2000s through the mid-2010s. If the CPS tenure distribution was held constant at its 2002 distribution, tenure-adjusted real earnings would have decreased between 2002 and 2014 (the dashed line in Figure 7). If tenure-specific earnings were held constant at its 2002 averages, real earnings would have exhibited a less cyclical time series pattern and would have a higher 2002-2014 growth rate than actual observed earnings. We

\footnotetext{
17 Furthermore, the sample sizes of individuals with both tenure and earnings data average just over 12,000 individuals each (biennial) year, which are quite small compared to the sample sizes from the LEHD.
} 
conclude that the CPS is similar to the LEHD in that both data sources are telling us that earnings growth during the last 10-15 years can be accounted for by the shifting tenure distribution.

\section{Vc. The Evolution of the Earnings-Tenure Profile}

The shifting tenure distribution is the natural result of declining hires and separations. One possible explanation for why hires and separations have fallen since the turn of the century is better matching between workers and employers, perhaps due to better information resulting from internet-enabled job search. Better matching should be (but need not be) associated with higher earnings. These higher earnings may appear at the start of the job, may appear during the first several years if there learning about match quality, or both. In this section, we address the role of starting earnings and the returns to tenure.

To isolate these respective components, we use regression analysis to evaluate the relative roles of the intercept and the slope of earnings-tenure profile. We estimate the following simple regression using a sample of jobs with five years or less of tenure:

$$
\text { (10) } \ln \left(w_{i t}\right)=\text { Intercept }_{t}+\beta_{1 t} * \text { Tenure }_{i t}+\beta_{2 t} * \text { Tenure }_{i t}^{2}+\beta_{3}\left(X_{i t}-\bar{X}\right)+\varepsilon_{i t} \text {. }
$$

The dependent variable is the natural log of real full quarter earnings. The explanatory variables $X_{i t}$ are age, age squared, and indicator variables for gender, education, race, and ethnicity. We enter the explanatory variables as mean-zero deviations from full sample means as a way to control for changing quality of the workforce across the business cycle. The year specific intercepts have the interpretation of initial earnings when tenure is zero and workforce composition is not changing over time.

The estimated year-specific intercepts and year-specific tenure coefficients from the LEHD full quarter earnings data are in Table 2. The first three columns present OLS results for select years: 2000, 2002, and 2008. Columns 4 through 6 of Table 2 mimic the first three columns, with the difference being we use an instrumental variables approach that follows Altonji and Shakotko (1987) and Abraham and Farber (1987). Because individuals in long- 
lasting jobs will earn more in all quarters, there is a positive correlation between tenure and the error term. We therefore use the difference between point-in-time job tenure and average job tenure (i.e., ultimate job tenure times one-half) as an instrument for tenure. ${ }^{18}$ For comparability with the CPS microdata, we present estimates on the "modified LEHD" data above, that is, we measure the tenure for a job that is dominant among consecutive quarter jobs, and ignore gaps in employment when calculating job tenure.

Looking at the OLS results in Table 2, returns to job tenure are quite high in the LEHD data, suggesting $40 \%$ earnings increases over the first five years of employment (see the bottom row of the table titled " 5 year implied growth"). There are two reasons that these estimates are far higher than previous estimates of the returns to job tenure. First, they are done on only the first five years of observed job tenure, in which returns to job tenure are much higher than in later years. Furthermore, they include returns to tenure in the first year during which, as Altonji and Williams (2005) note, earnings increases are exceptionally high. Consistent with the findings of previous studies, returns to tenure are far lower when instrumenting for job tenure with the difference between observed and average job tenure: these are in the range of $7 \%$ to $17 \%$, rather than $32 \%$ to $43 \%$.

We show OLS results from the CPS tenure supplement microdata in Table 3. The left three columns contain estimates from a CPS subsample with five or less years of tenure that mimics the LEHD sample in Table 2; the right three columns are from the full CPS sample. We find lower empirical returns-to-tenure in the CPS relative to the LEHD. Even for the subsample where we select jobs held for five years or less, the returns over the five-year implied growth rate are $21 \%$ to $25 \%$ in the CPS, which is lower than the $32 \%$ to $43 \%$ in the LEHD (and the full sample CPS estimates are lower than the estimates from the CPS sample with five or less years of tenure). One reason why the LEHD estimates are higher than the CPS estimates may be measurement error in reported job duration in the CPS, which would attenuate the estimates of the parameters from our regression specification. Indeed, when we look at the earnings-tenure profile from the CPS, we see individuals who report two years of tenure earn less than

\footnotetext{
${ }^{18}$ This instrument requires us to know completed job tenure, which causes some empirical difficulty. We consider the maximum completed tenure to be five years, and we therefore cannot estimate the IV specification for 20092013 for that maximum completed tenure category.
} 
individuals who report 13-23 months of tenure. ${ }^{19}$ Measurement error should not be as much of an issue in the LEHD data, which is an administrative records source where tenure is constructed from repeated observations of linked employer-employee matches, and does not involve any recall bias that is inherent in retrospective survey reports of tenure.

We are interested in how earnings evolve over time. Specifically, we measure starting earnings and implied earnings growth over the first five years of a job. This is captured in Figure 8 and Figure 9 for the LEHD and CPS, respectively. We recover starting earnings as the year specific intercepts from our regression specification. Notional "starting earnings" are higher in the IV specification than the OLS specification because returns to tenure are lower in the IV specification. For the LEHD data, in both the OLS and IV specifications (the top and bottom panels of Figure 8, respectively), we find that starting earnings are procyclical whereas the returns to tenure are countercyclical. The countercyclical returns to job tenure may be due to rigidity in real earnings: the model we estimate recovers a traditional returns-to-tenure estimate for each year. However, workers who entered their job at different points in time likely had starting earnings reflected from a different year. Nevertheless, the outcomes of this exercise are instructive: the sum of starting earnings and returns to tenure does not exhibit any cyclical pattern, but does exhibit a noticeable downward trend since its peak in 2004 (2003 in the IV results). The CPS full sample also exhibits this noticeable downward trend since 2002 (the top panel of Figure 9), with the trend definitely due to starting earnings rather than the returns to tenure. The downward trend in the CPS sample with five or less years of tenure (the bottom panel of Figure 9) starts in 2004.

Our consideration of earnings and job tenure helps to shed light on what may be inducing shifts in the job tenure distribution. Specifically, it could be that workers are better matched, as suggested by Hyatt and Spletzer (2013). If workers are better matched, and the workers benefit for those matches, then either starting earnings should increase, or the earnings-tenure profile should steepen. In fact, we find that starting earnings either exhibit no change or decrease slightly, and there is no obvious shift in the returns to job tenure. The LEHD and CPS results therefore lead us to conclude that there is no evidence that the shift in the job tenure distribution

\footnotetext{
${ }^{19}$ See Figure A-2 in the Appendix.
} 
is being driven by better matches for which workers are immediately compensated. The evidence is more consistent with factors that would cause tenure-specific earnings and starting earnings to decline slightly. Factors that might be at work could be that job match quality was worse due to lower rates of efficiency-enhancing employment reallocation, or weakening labor demand in the context of the 2001 and 2007-2009 recession. Overall, it is unlikely that improved job match quality dominates.

\section{Conclusions}

In first decade and a half of the new millennium, there has been a shift in the U.S. workforce away from short tenure jobs toward longer tenure jobs. Part of this was due to the ageing of the U.S. workforce and the shift in firm composition toward larger and older firms. However, much of this also had to do with the two labor market downturns associated with the 2001 and 2007-2009 recessions, in which hire and separation rates followed a "stair step" pattern. Over the decade and a half since the late 1990s, we can see this cyclical decline in the hiring rate move through the job tenure distribution, whereas tenure-specific separation rates explain considerably less of shifting job tenure. Although one of our major findings in this paper is that the recent decline in hires and separations has shifted the tenure distribution to the right, the literature has not yet determined why the hiring and separation rate has declined so dramatically since the turn of the century. We view this as an important area of further research.

We explored the relationship between the shifting job tenure distribution and worker earnings. In the LEHD and CPS, all earnings growth since the year 2000 is less than that which can be accounted for by changes in the job tenure distribution. We also find that for a sample of workers in their first five years of tenure, the sum of their starting earnings and their returns to tenure has declined since 2004. This is contrary to what one would expect if the declines in hires and separations, and thus the shift in the tenure distribution towards longer tenured jobs, was a result of better matching between workers and employers. In our earnings results as well, the weaker labor demand in the labor market downturns associated with the 2001 and 2007-2009 recessions play a dominant role. 


\section{References}

Abowd, John M., Bryce E. Stephens, Lars Vilhuber, Fredrik Andersson, Kevin L. McKinney, Marc Roemer, and Simon Woodcock. 2009. "The LEHD Infrastructure Files and the Creation of the Quarterly Workforce Indicators.” In Producer Dynamics, ed. Timothy Dunne, J. Bradford Jensen, and Mark J. Roberts. Chicago, IL: University of Chicago Press.

Abowd, John M. and Lars Vilhuber. 2011. "National Estimates of Gross Employment and Job Flows from the Quarterly Workforce Indicators with Demographic and Industry Detail," Journal of Econometrics, 161(1): 82-99.

Abraham, Katharine, and Henry S. Farber. 1987. “Job Duration, Seniority, and Earnings.” American Economic Review, 77(3): 278-297.

Altonji, Joseph, and Robert Shakotko. 1987. “Do Wages Rise with Job Seniority?” Review of Economic Studies, 54(3): 437-459.

Altonji, Joseph, and Nicolas Williams. 2005. "Do Wages Rise with Job Seniority? A Reassessment.” Industrial and Labor Relations Review, 58(3): 370-397.

Copeland, Craig. 2015. “Employee Tenure Trends: 1983-2014.” EBRI Notes, 36(2): 2-13.

Davis, Steven J., R. Jason Faberman, and John C. Haltiwanger. 2012. "Labor Market Flows in the Cross Section and over Time.” Journal of Monetary Economics 59(1): 1-18.

Davis, Steven, and John Haltiwanger. 2014. "Labor Market Fluidity and Economic Performance.” NBER Working Paper \#20479, published in the Proceedings of the Jackson Hole Symposium, Federal Reserve Bank of Kansas, available at https://www.kansascityfed.org/publicat/sympos/2014/2014Davis_Haltiwanger.pdf.

Decker, Ryan, John Haltiwanger, Ron Jarmin, and Javier Miranda. 2014a. “The Secular Decline in Business Dynamism in the U.S.” Unpublished draft, University of Maryland.

Decker, Ryan, John Haltiwanger, Ron Jarmin, and Javier Miranda. 2014b. "The Role of Entrepreneurship in US Job Creation and Economic Dynamism.” Journal of Economic Perspectives, 28(3): 3-24.

Dinlersoz, Emin, Henry Hyatt, and Hubert Janicki. 2016. "Who Works for Whom? Worker Sorting in a Model of Entrepreneurship with Heterogeneous Labor Markets.” IZA Discussion Paper \#9693.

Elsby, Michael, Ryan Michaels, and Gary Solon. 2009. “The Ins and Outs of Cyclical Unemployment.” American Economic Journal: Macroeconomics, 1(1): 84-110.

Faberman, R. Jason, and Alejandro Justiniano. 2015. "Job Switching and Wage Growth.” Chicago Fed Letter, No. 337. 
Farber, Henry. 1999. "Mobility and Stability: The Dynamics of Job Change in Labor Markets.” In Handbook of Labor Economics, Vol. 3B, ed. by O. Ashenfelter and D. Card. Amsterdam: Elsevier, 2439-2484.

Farber, Henry. 2008. "Employment Insecurity: The Decline in Worker-Firm Attachment in the United States.” Princeton University CEPS Working Paper No. 172.

Fujita, Shigeru, and Giuseppe Moscarini. 2013. “Recall and Unemployment.” NBER Working Paper \#19640.

Hollister, Matissa, and Kristin Smith. 2014. "Unmasking the Conflicting Trends in Job Tenure by Gender in the United States, 1983-2008.” American Sociological Review 79(1): 159-181.

Hyatt, Henry, Erika McEntarfer, Kevin McKinney, Stephen Tibbets, and Douglas Walton. 2014. "Job-to-Job (J2J) Flows: New Labor Market Statistics from Linked Employer-Employee Data.” JSM Proceedings, Business and Economics Statistics Section, pp. 231-245.

Hyatt, Henry R., and James R. Spletzer. 2013. “The Recent Decline in Employment Dynamics.” IZA Journal of Labor Economics, 2(5): 1-21.

Hyatt, Henry R., and James R. Spletzer. 2014. "Hires, Separations, and the Job Tenure Distribution in Administrative Earnings Records.” JSM Proceedings, Business and Economic Statistics Section, pp. 98-110.

Hyatt, Henry R., and James R. Spletzer. 2015. “The Recent Decline in Single Quarter Jobs.” U.S. Census Bureau: Center for Economic Studies Working Paper \#CES-15-05.

Jaeger, David, and Ann Stevens. 1999. "Is Job Stability in the United States Falling? Reconciling Trends in the Current Population Survey and Panel Study of Income Dynamics.” Journal of Labor Economics 17(4): S1-S28.

Jovanovic, Boyan, and Robert Moffitt. 1990. “An Estimate of a Sectoral Model of Labor Mobility.” Journal of Political Economy, 98(4): 827-852.

Molloy, Raven, Christopher L. Smith, and Abigail K. Wozniak. 2014. "Declining Migration within the U.S.: The Role of the Labor Market.” NBER Working Paper \#20065.

Neumark, David, Daniel Polsky, and Daniel Hansen, 1999, "Has Job Stability Declined Yet? New Evidence for the 1990's.” Journal of Labor Economics, 17(4): S29-64.

Pugsley, Benjamin, and Aysegul Sahin. 2015. “Grown-up Business Cycles.” Unpublished draft, Federal Reserve Bank of New York.

Shimer, Robert. 2012. "Reassessing the ins and outs of unemployment." Review of Economic Dynamics, 15(2): 127-148. 
Siemer, Michael. 2015. "Firm Entry and Employment Dynamics in the Great Recession." Unpublished draft, Federal Reserve Board.

Stevens, Ann. 2005. “The More Things Change, The More They Stay the Same: Trends in LongTerm Employment in the United States, 1969-2002.” NBER Working Paper \#11878.

Topel, Robert. 1991. "Specific Capital, Mobility, and Wages: Wages Rise with Job Seniority." Journal of Political Economy, 99(1): 145-176.

Topel, Robert H., and Michael P. Ward. 1992. "Job Mobility and the Careers of Young Men.” Quarterly Journal of Economics, 107(2): 439-479.

Yellen, Janet. 2014. "Labor Market Dynamics and Monetary Policy.” Available at http://www.federalreserve.gov/newsevents/speech/yellen20140822a.pdf. 
Figure 1: Tenure Distribution from the CPS

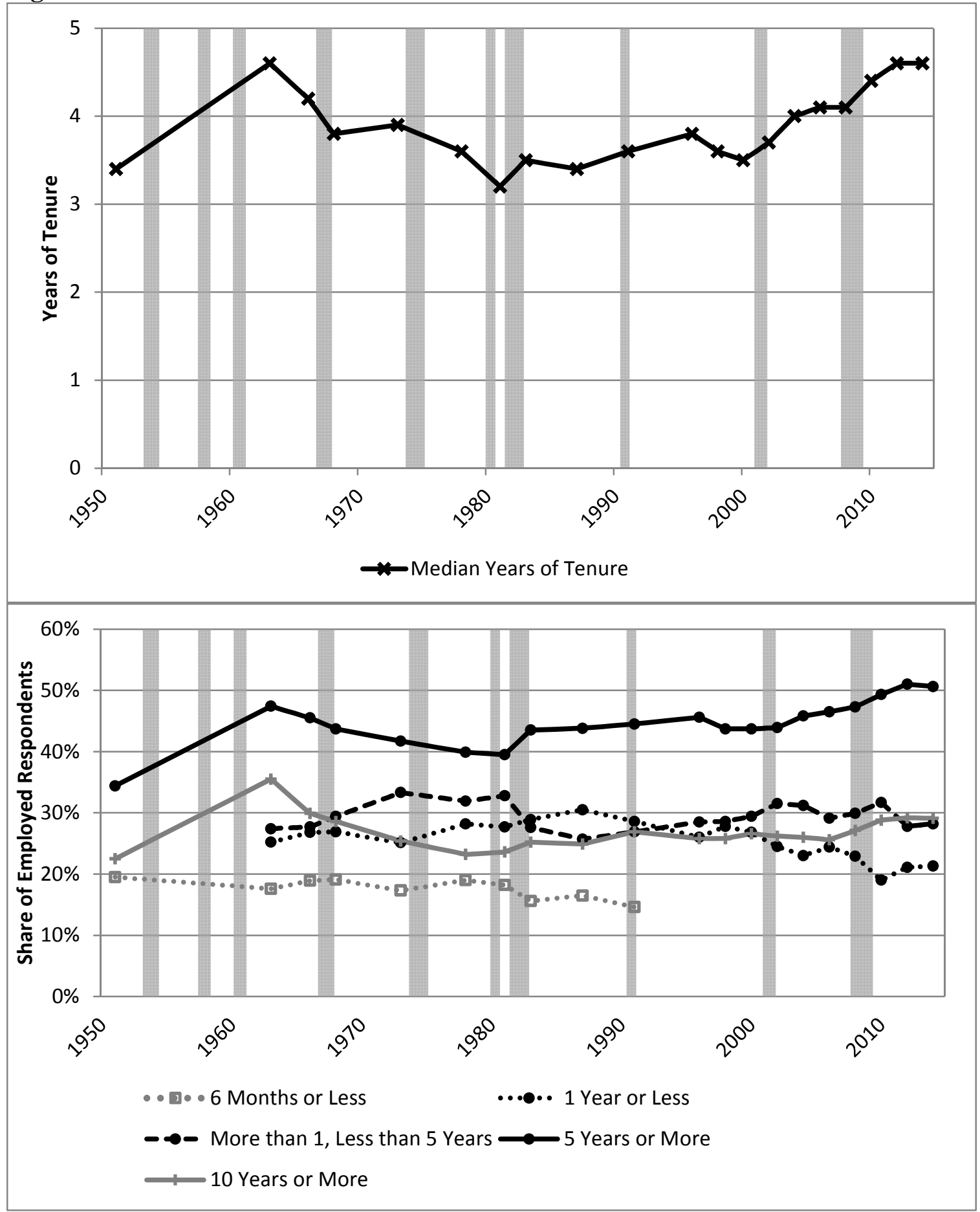

Source: CPS press releases and Monthly Labor Review articles, with tenure data from 1951, 1963, 1966, 1968, 1973, 1978, 1981, 1983, 1987, 1991, 1996, 1998, 2000, 2002, 2004, 2006, 2008, 2010, 2012, and 2014. Shaded areas indicate recessions. 
Figure 2: Tenure Distribution from the LEHD

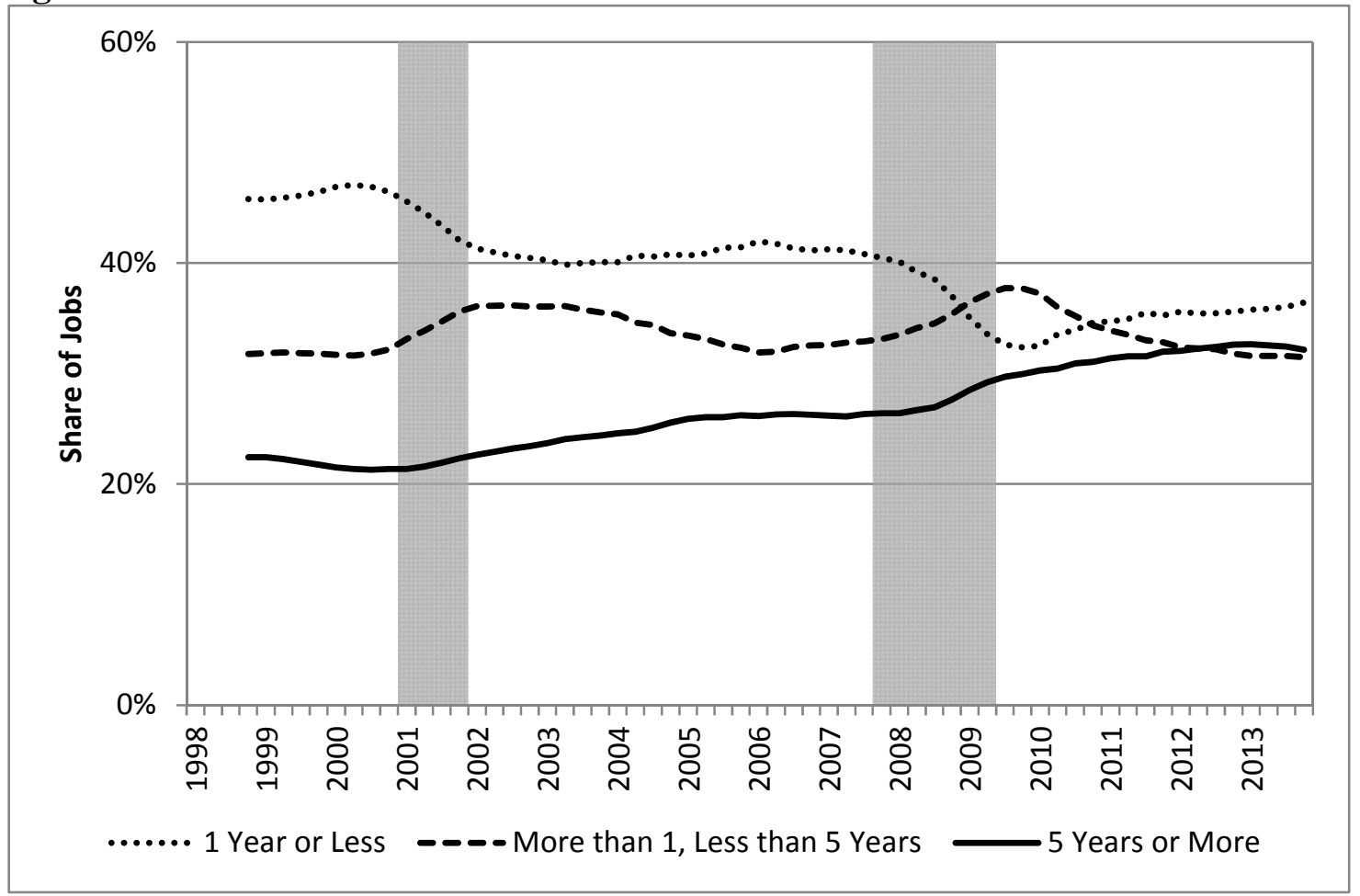

Source: Authors' tabulations of LEHD quarterly microdata, 1998:Q4 - 2013:Q4. Shaded areas indicate recessions. All series are seasonally adjusted. LEHD Jobs include all employer-employee combinations with positive wage and salary payments in a given quarter. 
Figure 3: Tenure Distributions from the LEHD and the CPS

LEHD and CPS data modified to represent similar concepts

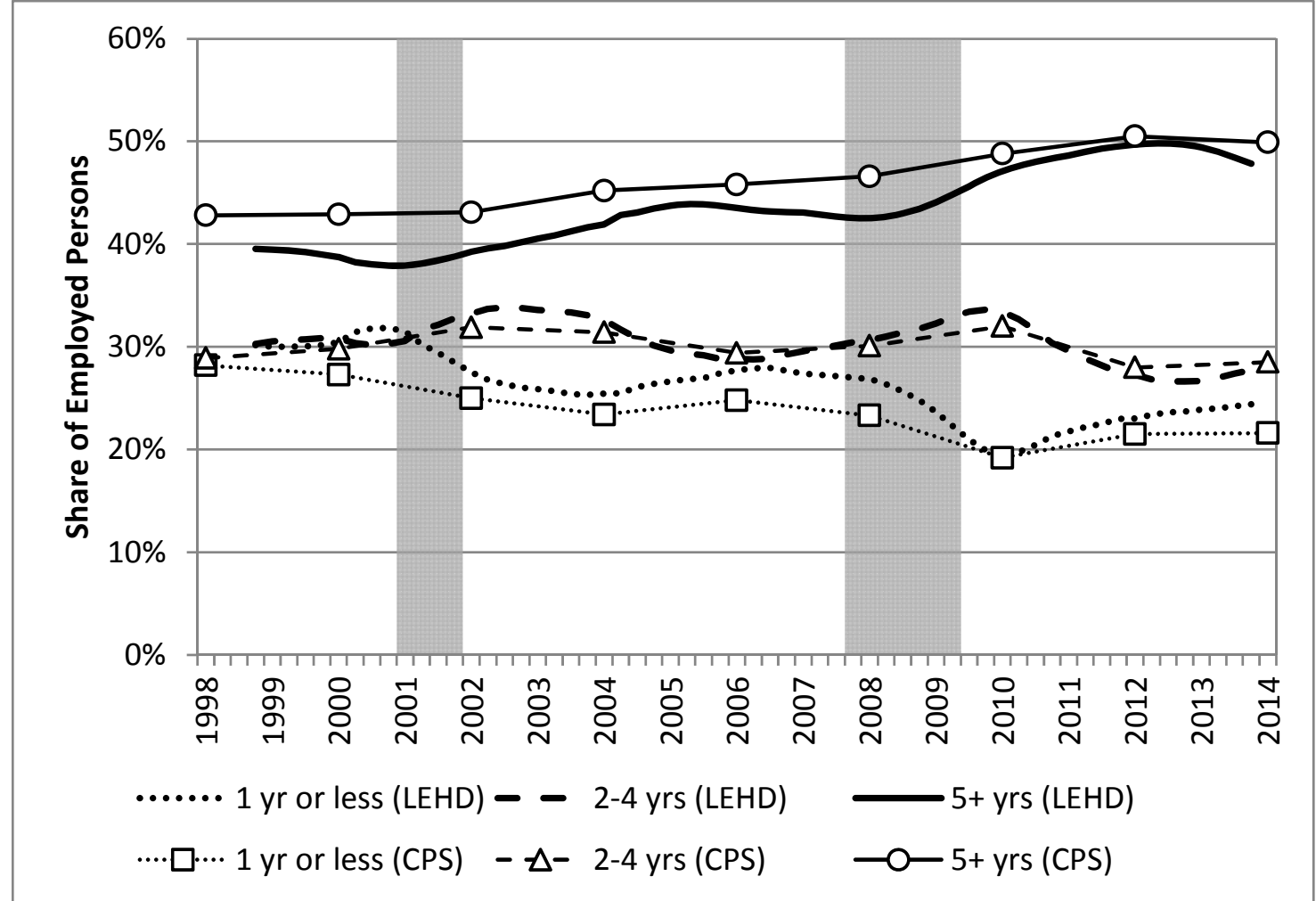

Source: Authors’ tabulations of LEHD quarterly microdata, 1998:Q4 - 2013:Q4, and CPS microdata, biennial tenure supplements 1998 - 2014. LEHD microdata modified as follows: (1) dominant jobs only, (2) jobs that appear in two consecutive quarters, and (3) tenure accumulates ignoring gaps. CPS microdata are modified to delete Federal Government employment. Shaded areas indicate recessions. All LEHD series are seasonally adjusted. 
Table 1: Decomposition of Shifting Tenure Distributions from LEHD and CPS

\begin{tabular}{|c|c|c|c|c|}
\hline & \multicolumn{3}{|c|}{$\overline{\text { Modified }}$} & \multirow{2}{*}{$\begin{array}{l}\text { Modified } \\
\text { LEHD }\end{array}$} \\
\hline & CPS & CPS & LEHD & \\
\hline \multicolumn{5}{|l|}{$\begin{array}{l}\text { Share of the employed } \\
\text { with } 5+\text { years of tenure: }\end{array}$} \\
\hline 1998 & .436 & .428 & .259 & .396 \\
\hline 2012 & .510 & .505 & .366 & .495 \\
\hline Change, 2012 - 1998 & .074 & .077 & .107 & .099 \\
\hline \multicolumn{5}{|l|}{$\begin{array}{l}\text { Percent of change } \\
\text { explained by: }\end{array}$} \\
\hline Worker Age & $52.4 \%$ & $50.0 \%$ & $25.4 \%$ & $30.8 \%$ \\
\hline Worker Gender & $-0.1 \%$ & $-0.1 \%$ & $0.1 \%$ & $-0.1 \%$ \\
\hline Worker Race-Ethnicity & $-1.5 \%$ & $-1.5 \%$ & $-1.1 \%$ & $-1.4 \%$ \\
\hline Worker Education & $2.6 \%$ & $2.1 \%$ & $-0.9 \%$ & $-1.3 \%$ \\
\hline Industry & $-8.9 \%$ & $-9.1 \%$ & $-5.7 \%$ & $-9.3 \%$ \\
\hline Occupation & $2.5 \%$ & $2.3 \%$ & & \\
\hline Firm Size & & & $3.1 \%$ & $3.3 \%$ \\
\hline Firm Age & & & $14.8 \%$ & $17.3 \%$ \\
\hline All Characteristics & $38.4 \%$ & $36.9 \%$ & $42.8 \%$ & $49.2 \%$ \\
\hline
\end{tabular}

Source: Authors' tabulations of LEHD quarterly microdata and CPS microdata. LEHD point estimates for the (not seasonally adjusted) fourth quarter of 1998 and 2012. The baseline LEHD data is a jobs-level dataset and so includes all employer-employee combinations with positive wage and salary payments in a given quarter. "Modified LEHD" microdata is as follows: (1) dominant jobs only, (2) jobs that appear in two consecutive quarters, and (3) tenure accumulates ignoring gaps. "Modified CPS" microdata delete Federal Government employment. The row labeled "Worker Education" uses a sample of individuals aged 25+. The row labeled "All Characteristics" assigns education to be "other" for all workers aged $<25$. 
Figure 4: Tenure-Specific Separation Rates from the LEHD

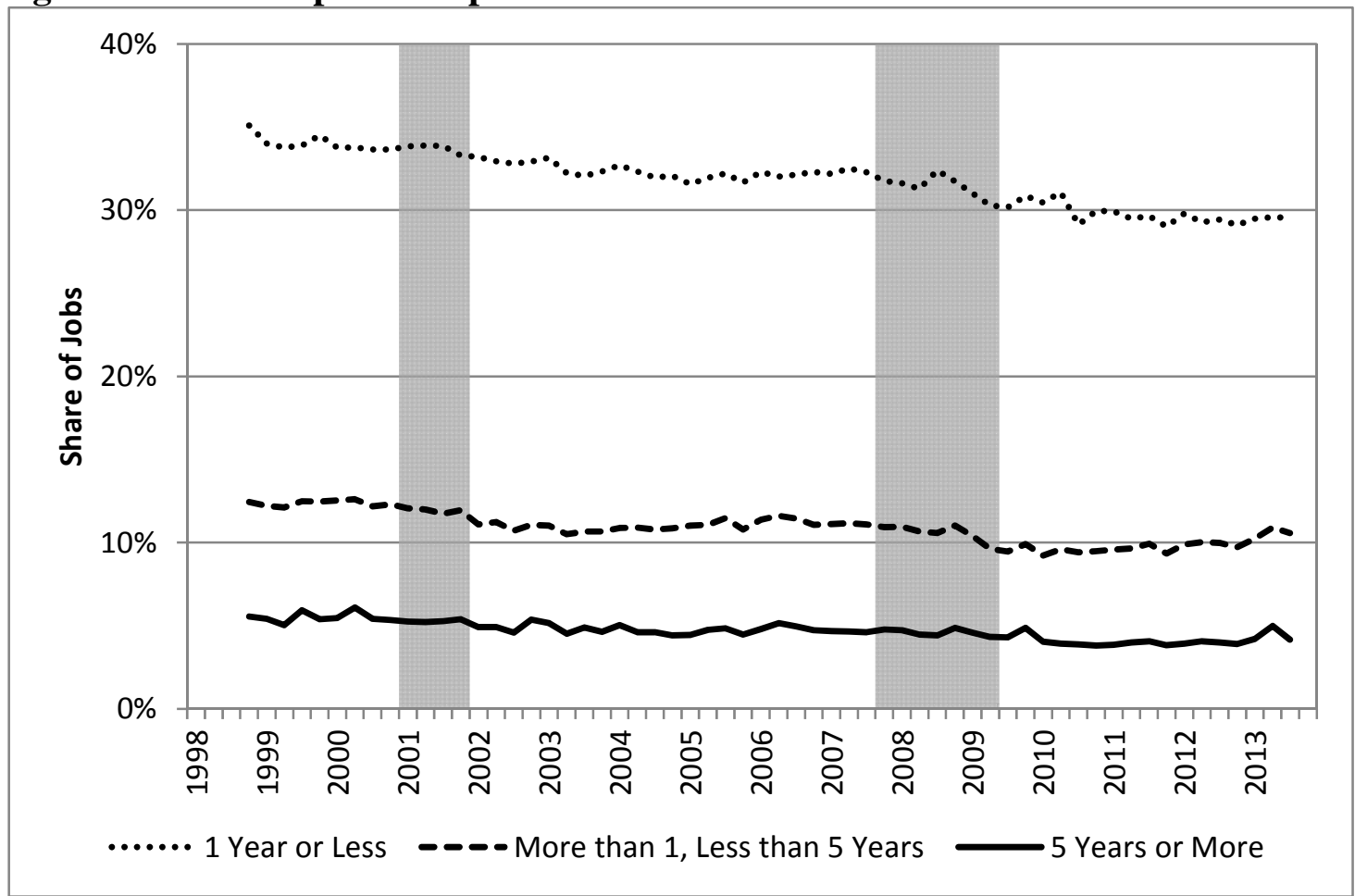

Source: Authors' tabulations of LEHD quarterly microdata, 1998:Q4 - 2013:Q4. Shaded areas indicate recessions. All series are seasonally adjusted. Jobs include all employer-employee combinations with positive wage and salary payments in a given quarter. 
Figure 5: Counterfactual Calculations of the LEHD Tenure Distribution
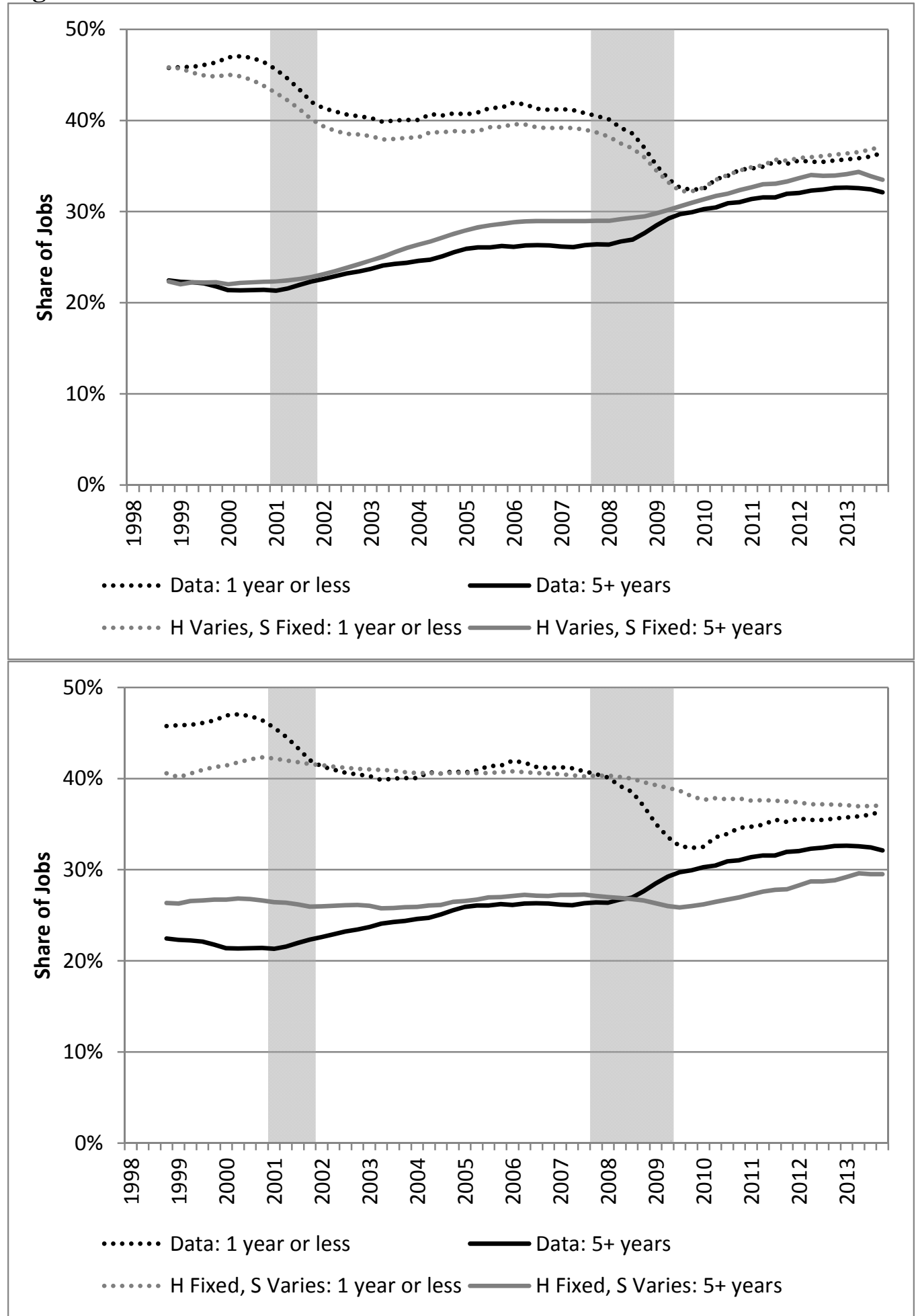

Source: Authors' tabulations of LEHD quarterly microdata, 1998:Q4 - 2013:Q4. Shaded areas indicate recessions. All series are seasonally adjusted. Jobs include all employeremployee combinations with positive wage and salary payments in a given quarter. See text for description of the "H varies, $\mathrm{S}$ fixed" and the " $\mathrm{H}$ fixed, $\mathrm{S}$ varies" series. 
Figure 6: Real Quarterly Earnings from the LEHD

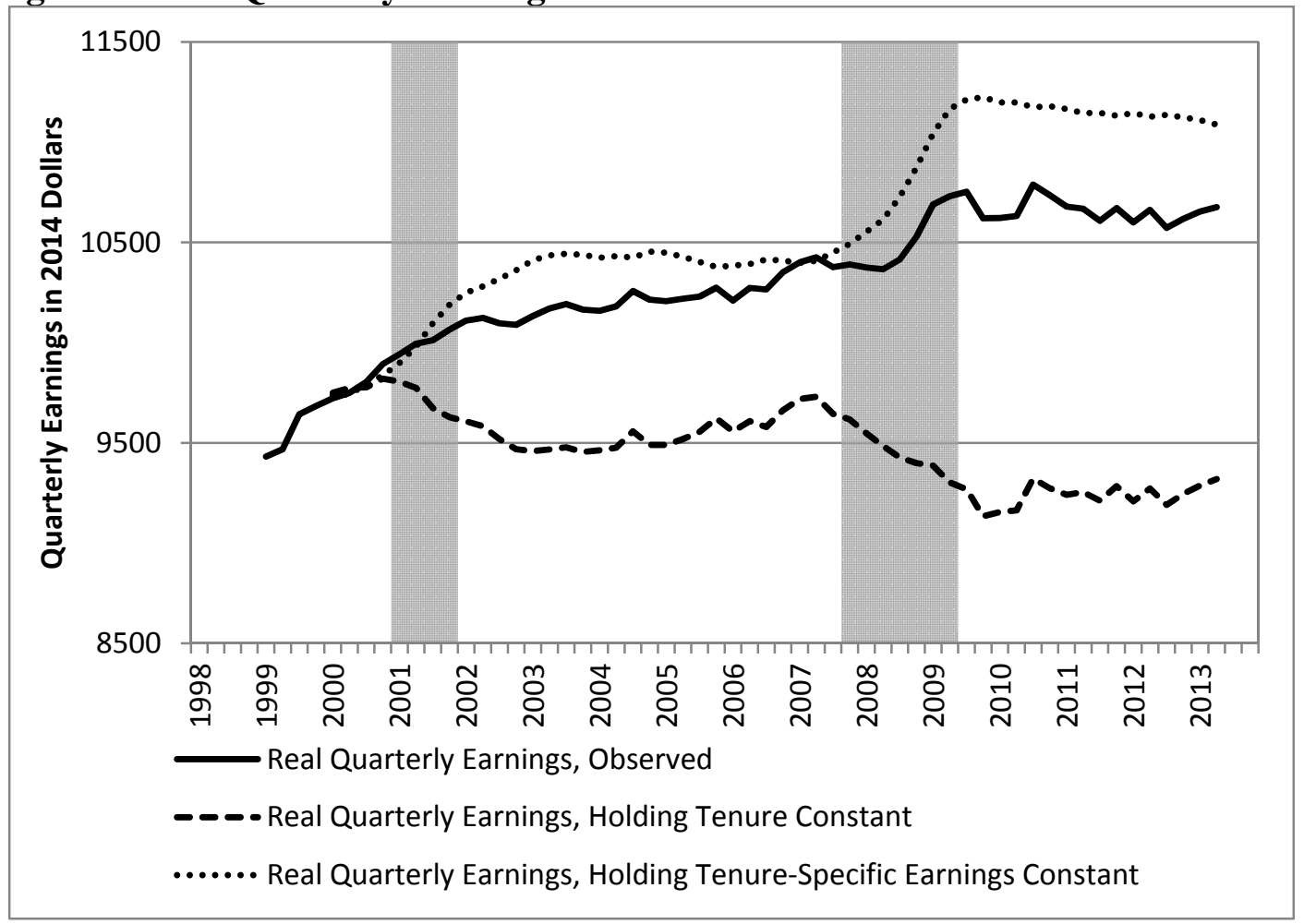

Source: Authors' tabulations of LEHD quarterly microdata, 1998:Q4 - 2013:Q4. Shaded areas indicate recessions. Earnings are "full quarter" earnings (see text). The counterfactual "Holding Tenure Constant" series holds the tenure distribution constant at its 2000 annual average. The counterfactual "Holding Earnings Constant" series holds average earnings by tenure constant at its 2000 annual average. All series are seasonally adjusted and expressed as 3-quarter centered moving averages. 
Figure 7: Real Weekly Earnings from the CPS Tenure Supplements

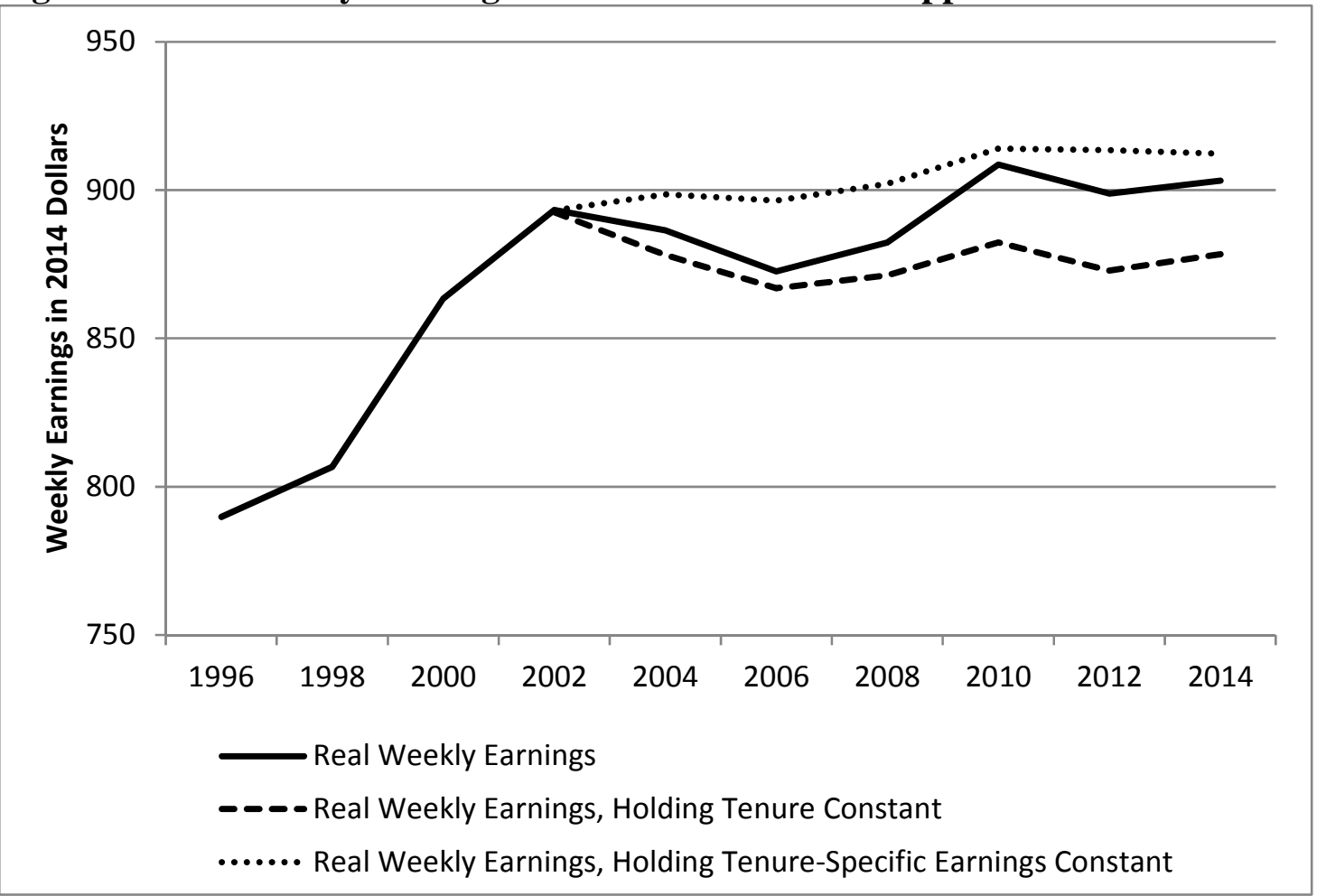

Source: Authors' tabulations of microdata from CPS tenure supplements, biennial 1996-2014. The counterfactual "Holding Tenure Constant" series holds the tenure distribution constant at its 2002 values. The counterfactual "Holding Earnings Constant” series holds average earnings by tenure constant at its 2002 values. 
Table 2: Earnings Regressions from the LEHD (selected coefficients)

\begin{tabular}{|c|c|c|c|c|c|c|}
\hline & \multicolumn{3}{|c|}{ OLS } & \multicolumn{3}{|c|}{ IV } \\
\hline & 2000 & 2002 & 2008 & 2000 & 2002 & 2008 \\
\hline Intercept & $\begin{array}{c}8.880 \\
(0.002)\end{array}$ & $\begin{array}{c}8.746 \\
(0.002)\end{array}$ & $\begin{array}{c}8.763 \\
(0.002)\end{array}$ & $\begin{array}{c}9.276 \\
(0.003)\end{array}$ & $\begin{array}{c}9.290 \\
(0.003)\end{array}$ & $\begin{array}{c}9.261 \\
(0.003)\end{array}$ \\
\hline Tenure & $\begin{array}{c}0.155 \\
(0.002)\end{array}$ & $\begin{array}{c}0.270 \\
(0.002)\end{array}$ & $\begin{array}{c}0.231 \\
(0.002)\end{array}$ & $\begin{array}{l}-0.209 \\
(0.003)\end{array}$ & $\begin{array}{l}-0.296 \\
(0.003)\end{array}$ & $\begin{array}{l}-0.255 \\
(0.003)\end{array}$ \\
\hline Tenure Squared & $\begin{array}{l}-0.019 \\
(0.000)\end{array}$ & $\begin{array}{l}-0.037 \\
(0.000)\end{array}$ & $\begin{array}{l}-0.030 \\
(0.000)\end{array}$ & $\begin{array}{c}0.045 \\
(0.001)\end{array}$ & $\begin{array}{c}0.066 \\
(0.001)\end{array}$ & $\begin{array}{c}0.056 \\
(0.001)\end{array}$ \\
\hline $\begin{array}{l}5 \text { year } \\
\text { implied growth }\end{array}$ & $32.1 \%$ & $42.9 \%$ & $41.0 \%$ & $7.3 \%$ & $16.7 \%$ & $13.4 \%$ \\
\hline $\begin{array}{r}\text { Source: Authors' an } \\
\text { OLS regre } \\
\text { years or le } \\
\text { parenthese } \\
\text { and year-s } \\
\text { gender, rac }\end{array}$ & $\begin{array}{l}\text { of a } 5 \% \mathrm{r} \\
1998: Q 4\end{array}$ & $\begin{array}{l}\text { om sample } \\
\text { 008:Q4 fo } \\
\text { ndent var } \\
\text { OLS and I } \\
\text { enure-squ }\end{array}$ & $\begin{array}{l}\text { LEHD qL } \\
\text { e IV regr } \\
\text { is } \ln (r e \\
\text { s pooled } \\
\text { variable } \\
\text { ions from }\end{array}$ & $\begin{array}{l}\text { microdat } \\
\text { Sample } \\
\text { quarter e } \\
\text { quarters } \\
\text { regressic } \\
\text { mple mea }\end{array}$ & $\begin{array}{l}\text { 98:Q4 - } 2 \\
\text { ll quarter } \\
\text { ngs). Stan } \\
\text { year-spe } \\
\text { icludes co }\end{array}$ & $\begin{array}{l}\text { Q4 for the } \\
\text { with five } \\
\text { errors in } \\
\text { intercepts } \\
\text { ls for age, }\end{array}$ \\
\hline
\end{tabular}

Table 3: Earnings Regressions from the CPS (selected coefficients)

\begin{tabular}{|c|c|c|c|c|c|c|}
\hline & \multicolumn{3}{|c|}{$\begin{array}{l}\text { OLS, Sample of Individuals } \\
\text { with } \leq 5 \text { Years of Tenure }\end{array}$} & \multicolumn{3}{|c|}{ OLS, Full Sample } \\
\hline & 2000 & 2002 & 2008 & 2000 & 2002 & 2008 \\
\hline Intercept & $\begin{array}{c}6.201 \\
(0.016)\end{array}$ & $\begin{array}{c}6.205 \\
(0.017)\end{array}$ & $\begin{array}{c}6.141 \\
(0.017)\end{array}$ & $\begin{array}{c}6.332 \\
(0.009)\end{array}$ & $\begin{array}{c}6.373 \\
(0.009)\end{array}$ & $\begin{array}{c}6.284 \\
(0.009)\end{array}$ \\
\hline Tenure & $\begin{array}{c}0.101 \\
(0.017)\end{array}$ & $\begin{array}{c}0.143 \\
(0.018)\end{array}$ & $\begin{array}{c}0.108 \\
(0.017)\end{array}$ & $\begin{array}{c}0.033 \\
(0.002)\end{array}$ & $\begin{array}{c}0.032 \\
(0.002)\end{array}$ & $\begin{array}{c}0.038 \\
(0.002)\end{array}$ \\
\hline Tenure Squared & $\begin{array}{l}-0.011 \\
(0.003)\end{array}$ & $\begin{array}{l}-0.019 \\
(0.003)\end{array}$ & $\begin{array}{l}-0.012 \\
(0.003)\end{array}$ & $\begin{array}{l}-0.001 \\
(0.000)\end{array}$ & $\begin{array}{l}-0.001 \\
(0.000)\end{array}$ & $\begin{array}{l}-0.001 \\
(0.000)\end{array}$ \\
\hline $\begin{array}{l}5 \text { year } \\
\text { implied growth }\end{array}$ & $21.8 \%$ & $23.5 \%$ & $25.0 \%$ & $15.1 \%$ & $14.6 \%$ & $17.2 \%$ \\
\hline $\begin{array}{r}\text { Source: } \text { Authors' } \\
\text { variable is } \\
\text { parenthese } \\
\text { over all y } \\
\text { Each regre } \\
\text { full sample }\end{array}$ & $\begin{array}{l}\text { of micro } \\
\text { l weekly } \\
\text { regressio } \\
\text { th year-sp } \\
\text { ncludes c } \\
\end{array}$ & $\begin{array}{l}\text { from CP } \\
\text { ings), tri } \\
\text { lll sample } \\
\text { c interce } \\
\text { ls for ag }\end{array}$ & $\begin{array}{l}\text { iennial tr } \\
\text { ed at the } \\
\text { mple of } i \\
\text { and year- } \\
\text { ender, ra }\end{array}$ & $\begin{array}{l}\text { suppleme } \\
\text { id } 99^{\text {th }} \text { pe } \\
\text { uals with } \\
\text { c tenure a } \\
\text { education }\end{array}$ & $\begin{array}{l}996-20 \\
\text { les. Star } \\
\text { ars of te } \\
\text { nure-squ } \\
\text { ered as }\end{array}$ & $\begin{array}{l}\text { Dependent } \\
\text { errors in } \\
\text { is pooled } \\
\text { variables. } \\
\text { tions from }\end{array}$ \\
\hline
\end{tabular}


Figure 8: Intercept and Tenure Effects from LEHD Earnings Regressions

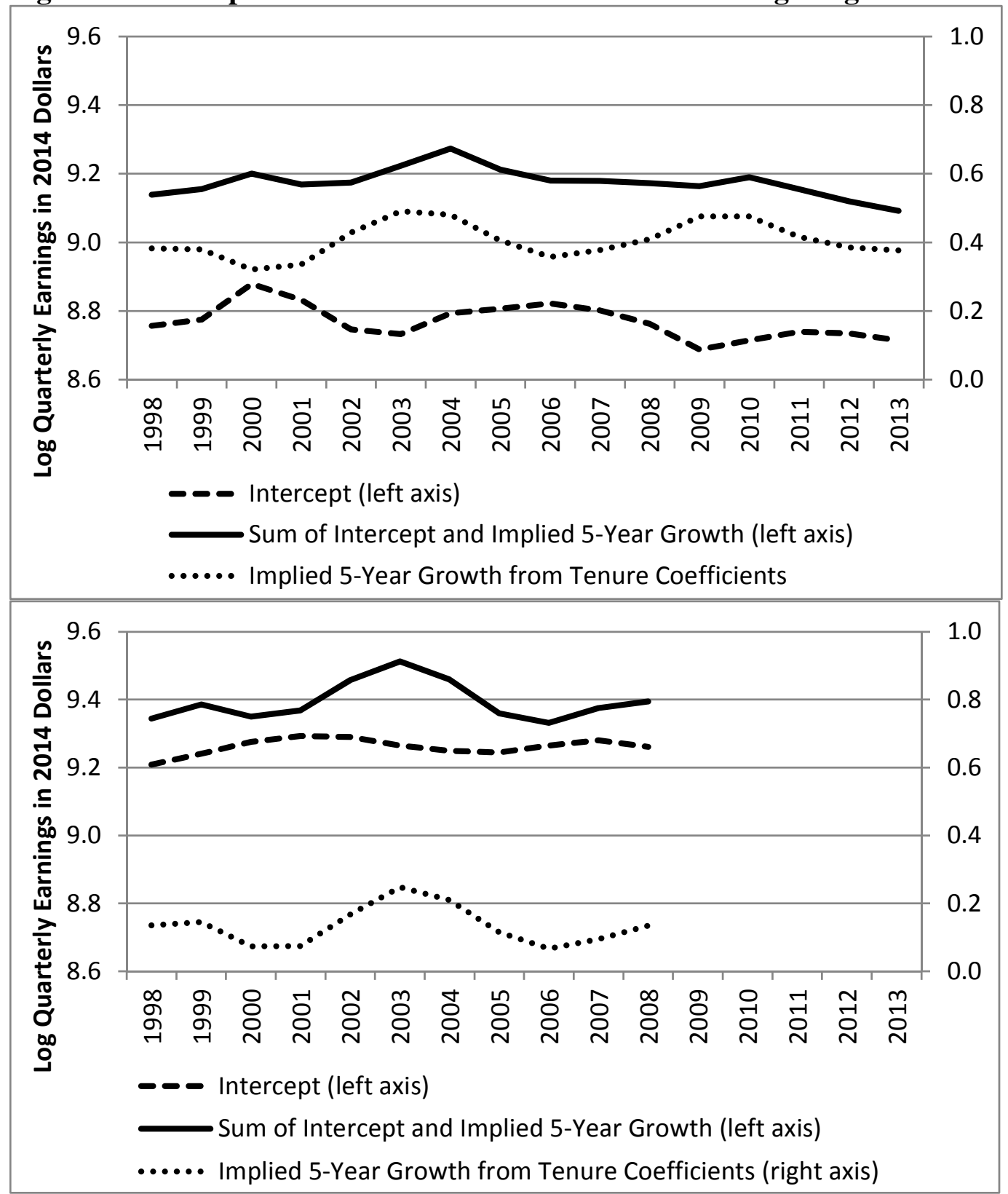

Source: Estimated intercept and 5 year growth calculated from regressions reported in Table 2. The top graph is from the OLS regression; the bottom graph is from the IV regression. 
Figure 9: Intercept and Tenure Effects from CPS Earnings Regressions

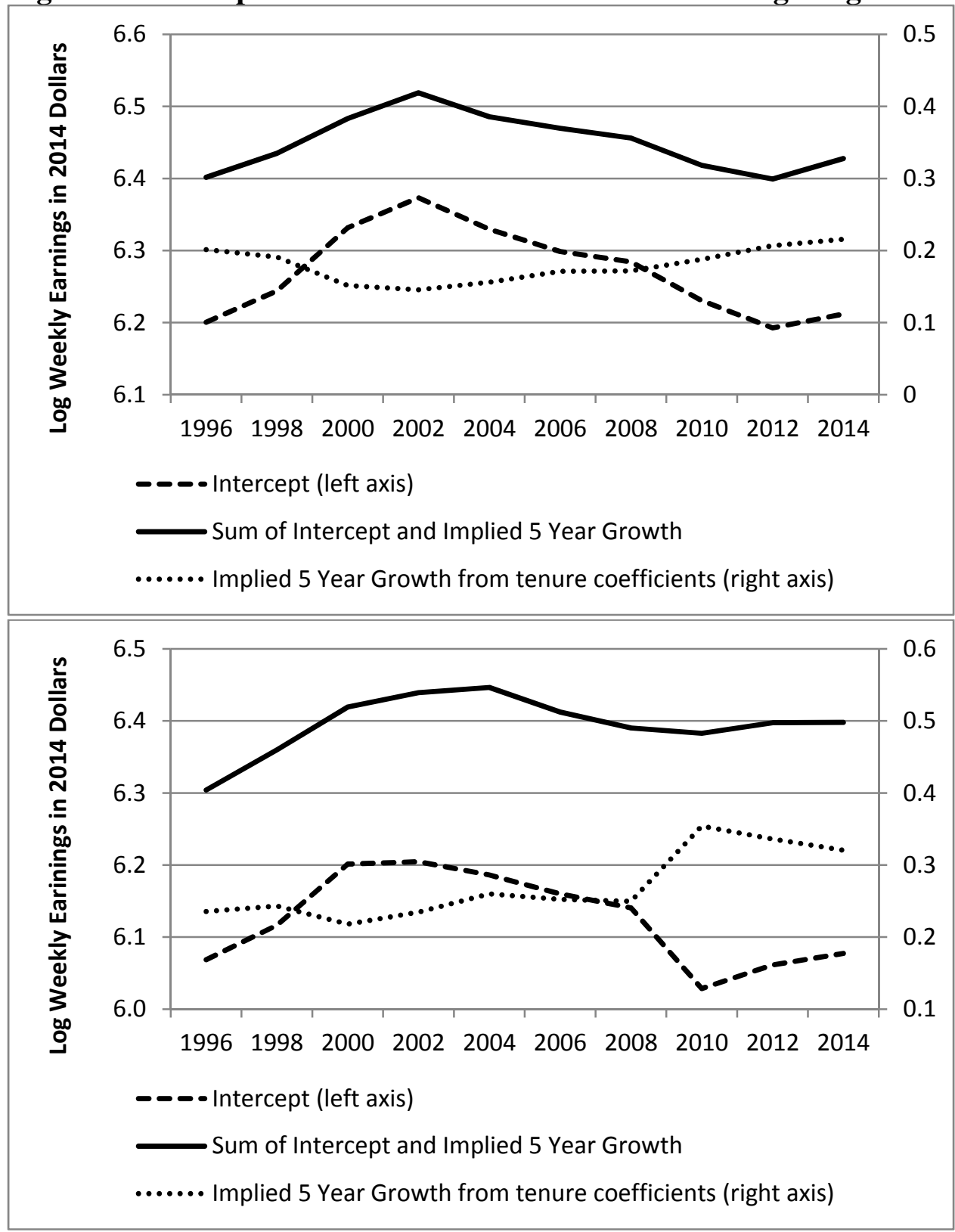

Source: Estimated intercept and 5 year growth calculated from regressions reported in Table 3. The top graph is from the full sample OLS regression; the bottom graph is from the OLS regression with a sample of individuals with $\leq 5$ years of tenure. 


\section{Appendix: A Detailed Analysis of CPS Tenure Data, 1983 - 2014}

As we note in the paper, there is a dramatic decline during the 1980s and 1990s in the share of employed men over the age of 45 who have held their jobs for ten years or more. The published CPS data show that $61.4 \%$ of employed men aged 45 and over had held their jobs for ten years or more in 1983, while in 1998, only 51.0\% had held their jobs for that long. However, the share of the total workforce that had held their jobs for 10 years or more increased slightly between 1983 and 1998, from $25.2 \%$ to $25.8 \%$.

To address questions about shifting job tenure during the 1980s and 1990s, and to distinguish those trends from more recent ones, we present the share of the workforce and job tenure by age and gender in Table A1 for select years of the CPS job tenure supplement: 1983, 1998, and 2014. These three years divide the 1983-2014 time series into a period (1983-1998) of declining stability for older males with constant tenure shares for the population as a whole, followed by a period (1998-2014) when the job tenure distribution is shifting toward longer tenure jobs for almost all age and gender groups. Table A2 presents the time series of employment and tenure data of all years in which the CPS tenure questions were asked, with corresponding graphs in Figure A1.

The statistics in Table A1 illustrate how to reconcile the notion that older men had less job security while the overall trend remained constant during the 1983 to 1998 time period. First, recall that the workforce was ageing during this time period. The percentage of young workers (defined here as 16-44 year olds) fell by 5.0\%, with a corresponding increase in the percentage of older workers (defined here as workers aged 45+). Second, note that the share of the employed with ten or more years of tenure is markedly higher for older persons (averaging 50.5\% during the 1983-1998 time period) than for younger persons (averaging 15.7\% during the 1983-1998 time period). The ageing of the workforce from a low tenure group into a high tenure group easily explains the small aggregate growth in the percent of the population with ten or more years of tenure, even when one subgroup - older men - exhibit substantial declines. 
The statistics in Figure A2 show CPS real weekly earnings from individuals who are in the outgoing rotation groups in the months that the tenure supplements were asked. The tenure categories on the horizontal axis are the tenure categories used in the questionnaire and published in the BLS job tenure press releases. As mentioned in the text, individuals who report two years of tenure earn less than individuals who report 13-23 months of tenure. 
Table A1: Tenure Distribution by Age and Gender, Select Years 1983-2014

\begin{tabular}{|c|c|c|c|c|c|c|c|}
\hline & $\begin{array}{c}16+ \\
\text { All } \\
\end{array}$ & $\begin{array}{l}16+ \\
\text { Men }\end{array}$ & $\begin{array}{c}16+ \\
\text { Women }\end{array}$ & $\begin{array}{c}16-44 \\
\text { Men }\end{array}$ & $\begin{array}{c}16-44 \\
\text { Women }\end{array}$ & $\begin{array}{l}45^{+} \\
\text {Men }\end{array}$ & $\begin{array}{c}45+ \\
\text { Women }\end{array}$ \\
\hline \multicolumn{8}{|l|}{ Fraction of Emp. } \\
\hline 1983 & $100 \%$ & $53.7 \%$ & $46.3 \%$ & $38.1 \%$ & $33.5 \%$ & $15.5 \%$ & $12.8 \%$ \\
\hline 1998 & $100 \%$ & $51.6 \%$ & $48.4 \%$ & $34.4 \%$ & $32.3 \%$ & $17.2 \%$ & $16.1 \%$ \\
\hline 2014 & $100 \%$ & $50.6 \%$ & $49.3 \%$ & $29.5 \%$ & $28.1 \%$ & $21.1 \%$ & $21.3 \%$ \\
\hline Diff 1983-1998 & $0 \%$ & $-2.1 \%$ & $2.1 \%$ & $-3.8 \%$ & $-1.2 \%$ & $1.7 \%$ & $3.3 \%$ \\
\hline Diff 1998-2014 & $0 \%$ & $-1.0 \%$ & $1.0 \%$ & $-4.9 \%$ & $-4.3 \%$ & $3.9 \%$ & $5.2 \%$ \\
\hline \multicolumn{8}{|l|}{ Tenure $\leq 1$ year } \\
\hline 1983 & $28.9 \%$ & $27.0 \%$ & $31.1 \%$ & $33.3 \%$ & $37.9 \%$ & $11.3 \%$ & $13.3 \%$ \\
\hline 1998 & $27.8 \%$ & $26.9 \%$ & $28.7 \%$ & $32.9 \%$ & $35.5 \%$ & $13.6 \%$ & $14.3 \%$ \\
\hline 2014 & $21.3 \%$ & $20.9 \%$ & $21.7 \%$ & $28.0 \%$ & $30.7 \%$ & $10.9 \%$ & $9.9 \%$ \\
\hline Diff 1983-1998 & $-1.1 \%$ & $-0.1 \%$ & $-2.4 \%$ & $-0.4 \%$ & $-2.4 \%$ & $2.3 \%$ & $1.0 \%$ \\
\hline Diff 1998-2014 & $-6.5 \%$ & $-6.0 \%$ & $-7.0 \%$ & $-4.9 \%$ & $-4.8 \%$ & $-2.7 \%$ & $-4.4 \%$ \\
\hline \multicolumn{8}{|l|}{ Tenure $2-4$ years } \\
\hline 1983 & $27.6 \%$ & $25.3 \%$ & $30.3 \%$ & $30.2 \%$ & $34.1 \%$ & $13.3 \%$ & $20.2 \%$ \\
\hline 1998 & $28.6 \%$ & $28.1 \%$ & $29.2 \%$ & $32.0 \%$ & $33.1 \%$ & $19.2 \%$ & $21.0 \%$ \\
\hline 2014 & $28.2 \%$ & $27.9 \%$ & $28.4 \%$ & $35.0 \%$ & $35.4 \%$ & $18.1 \%$ & $19.3 \%$ \\
\hline Diff 1983-1998 & $1.0 \%$ & $2.8 \%$ & $-1.1 \%$ & $1.8 \%$ & $-1.0 \%$ & $5.9 \%$ & $0.8 \%$ \\
\hline Diff 1998-2014 & $-0.4 \%$ & $-0.2 \%$ & $-0.8 \%$ & $3.0 \%$ & $2.3 \%$ & $-1.1 \%$ & $-1.7 \%$ \\
\hline \multicolumn{8}{|l|}{ Tenure 5-9 years } \\
\hline 1983 & $18.3 \%$ & $17.5 \%$ & $19.3 \%$ & $18.9 \%$ & $18.1 \%$ & $14.1 \%$ & $22.2 \%$ \\
\hline 1998 & $17.9 \%$ & $17.4 \%$ & $18.3 \%$ & $17.9 \%$ & $17.3 \%$ & $16.2 \%$ & $20.5 \%$ \\
\hline 2014 & $21.5 \%$ & $21.4 \%$ & $21.7 \%$ & $22.3 \%$ & $21.4 \%$ & $20.1 \%$ & $22.1 \%$ \\
\hline Diff 1983-1998 & $-0.4 \%$ & $-0.1 \%$ & $-1.0 \%$ & $-1.0 \%$ & $-0.8 \%$ & $2.1 \%$ & $-1.7 \%$ \\
\hline Diff 1998-2014 & $3.6 \%$ & $4.0 \%$ & $3.4 \%$ & $4.4 \%$ & $4.1 \%$ & $3.9 \%$ & $1.6 \%$ \\
\hline \multicolumn{8}{|l|}{ Tenure $\geq 10$ years } \\
\hline 1983 & $25.2 \%$ & $30.3 \%$ & $19.4 \%$ & $17.6 \%$ & $9.9 \%$ & $61.4 \%$ & $44.4 \%$ \\
\hline 1998 & $25.8 \%$ & $27.6 \%$ & $23.8 \%$ & $17.2 \%$ & $14.1 \%$ & $51.0 \%$ & $44.3 \%$ \\
\hline 2014 & $29.1 \%$ & $29.7 \%$ & $28.2 \%$ & $14.8 \%$ & $12.6 \%$ & $50.9 \%$ & $48.8 \%$ \\
\hline Diff 1983-1998 & $0.6 \%$ & $-2.7 \%$ & $4.4 \%$ & $-0.4 \%$ & $4.2 \%$ & $-10.4 \%$ & $0.0 \%$ \\
\hline Diff 1998-2014 & $3.3 \%$ & $2.1 \%$ & $4.4 \%$ & $-2.4 \%$ & $-1.5 \%$ & $-0.1 \%$ & $4.5 \%$ \\
\hline
\end{tabular}

Source: CPS press releases and Monthly Labor Review articles, with tenure data from 1983, 1998, and 2014. 
Table A2: Employment and Tenure Data, 1983-2014, by Age and Gender

\begin{tabular}{c|ccccccccc|}
$\begin{array}{c}\text { Employ } \\
\text { ment }\end{array}$ & $\begin{array}{c}16+ \\
\text { All }\end{array}$ & $\begin{array}{c}16+ \\
\text { Men }\end{array}$ & $\begin{array}{c}16+ \\
\text { Women }\end{array}$ & $\begin{array}{c}16-44 \\
\text { All }\end{array}$ & $\begin{array}{c}16-44 \\
\text { Men }\end{array}$ & $\begin{array}{c}16-44 \\
\text { Women }\end{array}$ & $\begin{array}{c}45+ \\
\text { All }\end{array}$ & $\begin{array}{c}45+ \\
\text { Men }\end{array}$ & $\begin{array}{c}45+ \\
\text { Women }\end{array}$ \\
\hline 1983 & $100.0 \%$ & $53.6 \%$ & $46.4 \%$ & $71.7 \%$ & $38.1 \%$ & $33.6 \%$ & $28.3 \%$ & $15.5 \%$ & $12.8 \%$ \\
1987 & $100.0 \%$ & $53.3 \%$ & $46.7 \%$ & $73.3 \%$ & $38.9 \%$ & $34.4 \%$ & $26.7 \%$ & $14.3 \%$ & $12.3 \%$ \\
1991 & $100.0 \%$ & $52.4 \%$ & $47.6 \%$ & $72.5 \%$ & $38.0 \%$ & $34.5 \%$ & $27.5 \%$ & $14.4 \%$ & $13.2 \%$ \\
1996 & $100.0 \%$ & $51.8 \%$ & $48.0 \%$ & $69.8 \%$ & $36.6 \%$ & $33.1 \%$ & $30.2 \%$ & $15.3 \%$ & $14.9 \%$ \\
1998 & $100.0 \%$ & $51.8 \%$ & $48.1 \%$ & $68.4 \%$ & $35.9 \%$ & $32.6 \%$ & $31.5 \%$ & $16.0 \%$ & $15.5 \%$ \\
2000 & $100.0 \%$ & $51.9 \%$ & $48.3 \%$ & $66.9 \%$ & $35.0 \%$ & $31.9 \%$ & $33.1 \%$ & $16.8 \%$ & $16.4 \%$ \\
2002 & $100.0 \%$ & $51.5 \%$ & $48.5 \%$ & $65.0 \%$ & $33.9 \%$ & $31.1 \%$ & $35.1 \%$ & $17.7 \%$ & $17.4 \%$ \\
2004 & $100.0 \%$ & $51.9 \%$ & $48.1 \%$ & $63.0 \%$ & $33.3 \%$ & $29.6 \%$ & $37.0 \%$ & $18.5 \%$ & $18.5 \%$ \\
2006 & $100.0 \%$ & $51.8 \%$ & $48.1 \%$ & $61.7 \%$ & $32.8 \%$ & $28.9 \%$ & $38.3 \%$ & $19.1 \%$ & $19.2 \%$ \\
2008 & $100.0 \%$ & $51.5 \%$ & $48.4 \%$ & $59.9 \%$ & $31.5 \%$ & $28.5 \%$ & $39.9 \%$ & $20.0 \%$ & $19.9 \%$ \\
2010 & $100.0 \%$ & $50.4 \%$ & $49.5 \%$ & $58.1 \%$ & $29.8 \%$ & $28.2 \%$ & $41.9 \%$ & $20.6 \%$ & $19.4 \%$ \\
2012 & $100.0 \%$ & $51.4 \%$ & $48.6 \%$ & $57.8 \%$ & $30.4 \%$ & $27.5 \%$ & $42.3 \%$ & $21.1 \%$ & $21.2 \%$ \\
2014 & $100.0 \%$ & $51.3 \%$ & $48.6 \%$ & $57.8 \%$ & $30.1 \%$ & $27.6 \%$ & $42.2 \%$ & $21.3 \%$ & $20.9 \%$ \\
\hline
\end{tabular}

\begin{tabular}{c|ccccccccc|}
$\begin{array}{c}\text { Tenure } \\
1 \text { year or } \\
\text { less }\end{array}$ & $\begin{array}{c}16+ \\
\text { All }\end{array}$ & $\begin{array}{c}16+ \\
\text { Men }\end{array}$ & $\begin{array}{c}16+ \\
\text { Women }\end{array}$ & $\begin{array}{c}16-44 \\
\text { All }\end{array}$ & $\begin{array}{c}16-44 \\
\text { Men }\end{array}$ & $\begin{array}{c}16-44 \\
\text { Women }\end{array}$ & $\begin{array}{c}45+ \\
\text { All }\end{array}$ & $\begin{array}{c}45+ \\
\text { Men }\end{array}$ & $\begin{array}{c}4+ \\
\text { Women }\end{array}$ \\
\hline 1983 & $28.9 \%$ & $27.0 \%$ & $31.1 \%$ & $35.5 \%$ & $33.3 \%$ & $37.9 \%$ & $12.2 \%$ & $11.3 \%$ & $13.3 \%$ \\
1987 & $30.5 \%$ & $28.2 \%$ & $33.1 \%$ & $36.6 \%$ & $34.0 \%$ & $39.5 \%$ & $13.7 \%$ & $12.5 \%$ & $15.1 \%$ \\
1991 & $28.6 \%$ & $26.6 \%$ & $30.8 \%$ & $34.1 \%$ & $31.6 \%$ & $36.8 \%$ & $14.2 \%$ & $13.2 \%$ & $15.2 \%$ \\
1996 & $26.0 \%$ & $25.1 \%$ & $27.0 \%$ & $31.9 \%$ & $30.8 \%$ & $33.1 \%$ & $12.3 \%$ & $11.5 \%$ & $13.2 \%$ \\
1998 & $27.8 \%$ & $26.9 \%$ & $28.7 \%$ & $34.1 \%$ & $32.9 \%$ & $35.5 \%$ & $13.9 \%$ & $13.6 \%$ & $14.3 \%$ \\
2000 & $26.8 \%$ & $25.6 \%$ & $28.1 \%$ & $33.7 \%$ & $31.8 \%$ & $35.7 \%$ & $12.9 \%$ & $12.7 \%$ & $13.3 \%$ \\
2002 & $24.5 \%$ & $23.5 \%$ & $25.6 \%$ & $31.3 \%$ & $29.7 \%$ & $33.0 \%$ & $12.0 \%$ & $11.6 \%$ & $12.6 \%$ \\
2004 & $23.0 \%$ & $22.4 \%$ & $23.7 \%$ & $30.3 \%$ & $29.2 \%$ & $31.4 \%$ & $10.7 \%$ & $10.1 \%$ & $11.4 \%$ \\
2006 & $24.4 \%$ & $23.9 \%$ & $24.9 \%$ & $31.7 \%$ & $30.6 \%$ & $33.0 \%$ & $12.6 \%$ & $12.4 \%$ & $12.8 \%$ \\
2008 & $22.9 \%$ & $22.4 \%$ & $23.5 \%$ & $30.6 \%$ & $29.7 \%$ & $31.6 \%$ & $11.4 \%$ & $11.0 \%$ & $11.9 \%$ \\
2010 & $19.0 \%$ & $18.5 \%$ & $19.4 \%$ & $26.0 \%$ & $25.0 \%$ & $27.0 \%$ & $9.3 \%$ & $9.2 \%$ & $9.6 \%$ \\
2012 & $21.1 \%$ & $21.0 \%$ & $21.3 \%$ & $28.6 \%$ & $27.9 \%$ & $29.4 \%$ & $10.9 \%$ & $11.2 \%$ & $10.6 \%$ \\
2014 & $21.3 \%$ & $20.9 \%$ & $21.7 \%$ & $29.2 \%$ & $28.0 \%$ & $30.7 \%$ & $10.4 \%$ & $10.9 \%$ & $9.9 \%$ \\
\hline
\end{tabular}


Table A2: Employment and Tenure Data, 1983-2014, by Age and Gender (continued)

\begin{tabular}{c|ccccccccc|}
$\begin{array}{c}\text { Tenure } \\
2-4 \text { years }\end{array}$ & $\begin{array}{c}16+ \\
\text { All }\end{array}$ & $\begin{array}{c}16+ \\
\text { Men }\end{array}$ & $\begin{array}{c}16+ \\
\text { Women }\end{array}$ & $\begin{array}{c}16-44 \\
\text { All }\end{array}$ & $\begin{array}{c}16-44 \\
\text { Men }\end{array}$ & $\begin{array}{c}16-44 \\
\text { Women }\end{array}$ & $\begin{array}{c}45+ \\
\text { All }\end{array}$ & $\begin{array}{c}45+ \\
\text { Men }\end{array}$ & $\begin{array}{c}45+ \\
\text { Women }\end{array}$ \\
\hline 1983 & $27.6 \%$ & $25.3 \%$ & $30.3 \%$ & $32.0 \%$ & $30.2 \%$ & $34.1 \%$ & $16.4 \%$ & $13.3 \%$ & $20.2 \%$ \\
1987 & $25.7 \%$ & $24.5 \%$ & $27.1 \%$ & $29.0 \%$ & $28.1 \%$ & $30.1 \%$ & $16.6 \%$ & $14.7 \%$ & $18.8 \%$ \\
1991 & $26.9 \%$ & $25.8 \%$ & $28.1 \%$ & $30.2 \%$ & $29.6 \%$ & $31.0 \%$ & $18.0 \%$ & $15.8 \%$ & $20.5 \%$ \\
1996 & $28.5 \%$ & $27.8 \%$ & $29.3 \%$ & $32.4 \%$ & $31.6 \%$ & $33.2 \%$ & $19.7 \%$ & $18.6 \%$ & $20.6 \%$ \\
1998 & $28.6 \%$ & $28.1 \%$ & $29.2 \%$ & $32.5 \%$ & $32.0 \%$ & $33.1 \%$ & $20.0 \%$ & $19.2 \%$ & $21.0 \%$ \\
2000 & $29.4 \%$ & $28.8 \%$ & $30.1 \%$ & $33.7 \%$ & $33.3 \%$ & $34.1 \%$ & $20.8 \%$ & $19.4 \%$ & $22.3 \%$ \\
2002 & $31.5 \%$ & $30.7 \%$ & $32.3 \%$ & $36.5 \%$ & $35.7 \%$ & $37.4 \%$ & $22.3 \%$ & $21.3 \%$ & $23.3 \%$ \\
2004 & $31.2 \%$ & $30.5 \%$ & $31.9 \%$ & $36.5 \%$ & $35.8 \%$ & $37.2 \%$ & $22.1 \%$ & $20.8 \%$ & $23.5 \%$ \\
2006 & $29.1 \%$ & $28.8 \%$ & $29.4 \%$ & $34.3 \%$ & $34.0 \%$ & $34.7 \%$ & $20.8 \%$ & $20.1 \%$ & $21.4 \%$ \\
2008 & $29.9 \%$ & $29.4 \%$ & $30.4 \%$ & $36.5 \%$ & $35.9 \%$ & $37.1 \%$ & $20.0 \%$ & $19.3 \%$ & $20.7 \%$ \\
2010 & $31.7 \%$ & $30.6 \%$ & $32.8 \%$ & $39.1 \%$ & $37.8 \%$ & $40.5 \%$ & $21.4 \%$ & $20.1 \%$ & $23.2 \%$ \\
2012 & $27.8 \%$ & $27.5 \%$ & $28.2 \%$ & $34.7 \%$ & $34.3 \%$ & $35.2 \%$ & $18.3 \%$ & $17.7 \%$ & $19.1 \%$ \\
2014 & $28.2 \%$ & $27.9 \%$ & $28.4 \%$ & $35.2 \%$ & $35.0 \%$ & $35.4 \%$ & $18.7 \%$ & $18.1 \%$ & $19.3 \%$ \\
\hline
\end{tabular}

\begin{tabular}{c|ccccccccc|}
$\begin{array}{c}\text { Tenure } \\
\text { 5-9 years }\end{array}$ & $\begin{array}{c}16+ \\
\text { All }\end{array}$ & $\begin{array}{c}16+ \\
\text { Men }\end{array}$ & $\begin{array}{c}16+ \\
\text { Women }\end{array}$ & $\begin{array}{c}16-44 \\
\text { All }\end{array}$ & $\begin{array}{c}16-44 \\
\text { Men }\end{array}$ & $\begin{array}{c}16-44 \\
\text { Women }\end{array}$ & $\begin{array}{c}45+ \\
\text { All }\end{array}$ & $\begin{array}{c}45+ \\
\text { Men }\end{array}$ & $\begin{array}{c}45+ \\
\text { Women }\end{array}$ \\
\hline 1983 & $18.3 \%$ & $17.5 \%$ & $19.3 \%$ & $18.5 \%$ & $18.9 \%$ & $18.1 \%$ & $17.7 \%$ & $14.1 \%$ & $22.2 \%$ \\
1987 & $18.9 \%$ & $18.6 \%$ & $19.3 \%$ & $19.2 \%$ & $19.8 \%$ & $18.5 \%$ & $18.1 \%$ & $15.4 \%$ & $21.4 \%$ \\
1991 & $17.6 \%$ & $17.5 \%$ & $17.7 \%$ & $17.8 \%$ & $18.5 \%$ & $17.1 \%$ & $16.9 \%$ & $14.9 \%$ & $19.1 \%$ \\
1996 & $19.8 \%$ & $19.1 \%$ & $20.5 \%$ & $19.9 \%$ & $19.9 \%$ & $20.1 \%$ & $19.4 \%$ & $17.4 \%$ & $21.4 \%$ \\
1998 & $17.9 \%$ & $17.4 \%$ & $18.3 \%$ & $17.6 \%$ & $17.9 \%$ & $17.3 \%$ & $18.3 \%$ & $16.2 \%$ & $20.5 \%$ \\
2000 & $17.1 \%$ & $17.3 \%$ & $17.0 \%$ & $17.0 \%$ & $17.4 \%$ & $16.6 \%$ & $17.4 \%$ & $17.0 \%$ & $17.9 \%$ \\
2002 & $17.7 \%$ & $17.7 \%$ & $17.7 \%$ & $17.4 \%$ & $18.3 \%$ & $16.5 \%$ & $18.4 \%$ & $16.7 \%$ & $20.0 \%$ \\
2004 & $19.8 \%$ & $19.6 \%$ & $20.1 \%$ & $19.7 \%$ & $20.1 \%$ & $19.2 \%$ & $20.1 \%$ & $18.7 \%$ & $21.5 \%$ \\
2006 & $20.9 \%$ & $20.7 \%$ & $21.2 \%$ & $20.8 \%$ & $21.0 \%$ & $20.6 \%$ & $21.1 \%$ & $20.1 \%$ & $22.1 \%$ \\
2008 & $20.2 \%$ & $19.9 \%$ & $20.4 \%$ & $19.8 \%$ & $20.0 \%$ & $19.4 \%$ & $20.8 \%$ & $19.6 \%$ & $21.8 \%$ \\
2010 & $20.5 \%$ & $20.8 \%$ & $20.2 \%$ & $20.2 \%$ & $21.1 \%$ & $19.3 \%$ & $20.9 \%$ & $20.3 \%$ & $21.4 \%$ \\
2012 & $21.8 \%$ & $21.3 \%$ & $22.2 \%$ & $22.2 \%$ & $22.6 \%$ & $21.7 \%$ & $21.2 \%$ & $19.5 \%$ & $22.8 \%$ \\
2014 & $21.5 \%$ & $21.4 \%$ & $21.7 \%$ & $21.8 \%$ & $22.3 \%$ & $21.4 \%$ & $21.1 \%$ & $20.1 \%$ & $22.1 \%$ \\
\hline
\end{tabular}


Table A2: Employment and Tenure Data, 1983-2014, by Age and Gender (continued)

\begin{tabular}{c|ccccccccc|}
$\begin{array}{c}\text { Tenure } \\
10 \text { years } \\
\text { or more }\end{array}$ & $\begin{array}{c}16+ \\
\text { All }\end{array}$ & $\begin{array}{c}16+ \\
\text { Men }\end{array}$ & $\begin{array}{c}16+ \\
\text { Women }\end{array}$ & $\begin{array}{c}16-44 \\
\text { All }\end{array}$ & $\begin{array}{c}16-44 \\
\text { Men }\end{array}$ & $\begin{array}{c}16-44 \\
\text { Women }\end{array}$ & $\begin{array}{c}45+ \\
\text { All }\end{array}$ & $\begin{array}{c}45+ \\
\text { Men }\end{array}$ & $\begin{array}{c}45+ \\
\text { Women }\end{array}$ \\
\hline 1983 & $25.2 \%$ & $30.3 \%$ & $19.4 \%$ & $14.0 \%$ & $17.6 \%$ & $9.9 \%$ & $53.7 \%$ & $61.4 \%$ & $44.3 \%$ \\
1987 & $24.9 \%$ & $28.7 \%$ & $20.6 \%$ & $15.2 \%$ & $18.0 \%$ & $11.9 \%$ & $51.5 \%$ & $57.4 \%$ & $44.7 \%$ \\
1991 & $26.9 \%$ & $30.2 \%$ & $23.4 \%$ & $17.9 \%$ & $20.4 \%$ & $15.1 \%$ & $50.9 \%$ & $56.1 \%$ & $45.2 \%$ \\
1996 & $25.8 \%$ & $27.9 \%$ & $23.3 \%$ & $15.8 \%$ & $17.8 \%$ & $13.6 \%$ & $48.7 \%$ & $52.5 \%$ & $44.8 \%$ \\
1998 & $25.8 \%$ & $27.6 \%$ & $23.8 \%$ & $15.7 \%$ & $17.2 \%$ & $14.1 \%$ & $47.7 \%$ & $51.0 \%$ & $44.3 \%$ \\
2000 & $26.6 \%$ & $28.4 \%$ & $24.8 \%$ & $15.6 \%$ & $17.4 \%$ & $13.5 \%$ & $48.8 \%$ & $51.0 \%$ & $46.6 \%$ \\
2002 & $26.2 \%$ & $28.0 \%$ & $24.4 \%$ & $14.8 \%$ & $16.3 \%$ & $13.1 \%$ & $47.3 \%$ & $50.4 \%$ & $44.1 \%$ \\
2004 & $26.0 \%$ & $27.5 \%$ & $24.2 \%$ & $13.6 \%$ & $14.8 \%$ & $12.1 \%$ & $47.0 \%$ & $50.5 \%$ & $43.6 \%$ \\
2006 & $25.6 \%$ & $26.5 \%$ & $24.5 \%$ & $13.1 \%$ & $14.4 \%$ & $11.7 \%$ & $45.5 \%$ & $47.4 \%$ & $43.7 \%$ \\
2008 & $27.1 \%$ & $28.3 \%$ & $25.7 \%$ & $13.1 \%$ & $14.4 \%$ & $11.8 \%$ & $47.8 \%$ & $50.1 \%$ & $45.6 \%$ \\
2010 & $28.8 \%$ & $30.0 \%$ & $27.5 \%$ & $14.6 \%$ & $16.1 \%$ & $13.2 \%$ & $48.4 \%$ & $50.4 \%$ & $45.8 \%$ \\
2012 & $29.2 \%$ & $30.1 \%$ & $28.3 \%$ & $14.5 \%$ & $15.2 \%$ & $13.7 \%$ & $49.5 \%$ & $51.6 \%$ & $47.4 \%$ \\
2014 & $29.1 \%$ & $29.7 \%$ & $28.2 \%$ & $13.7 \%$ & $14.8 \%$ & $12.6 \%$ & $49.8 \%$ & $50.9 \%$ & $48.8 \%$ \\
\hline
\end{tabular}


Figure A1: Employment and Tenure Data, 1983-2014, by Age and Gender
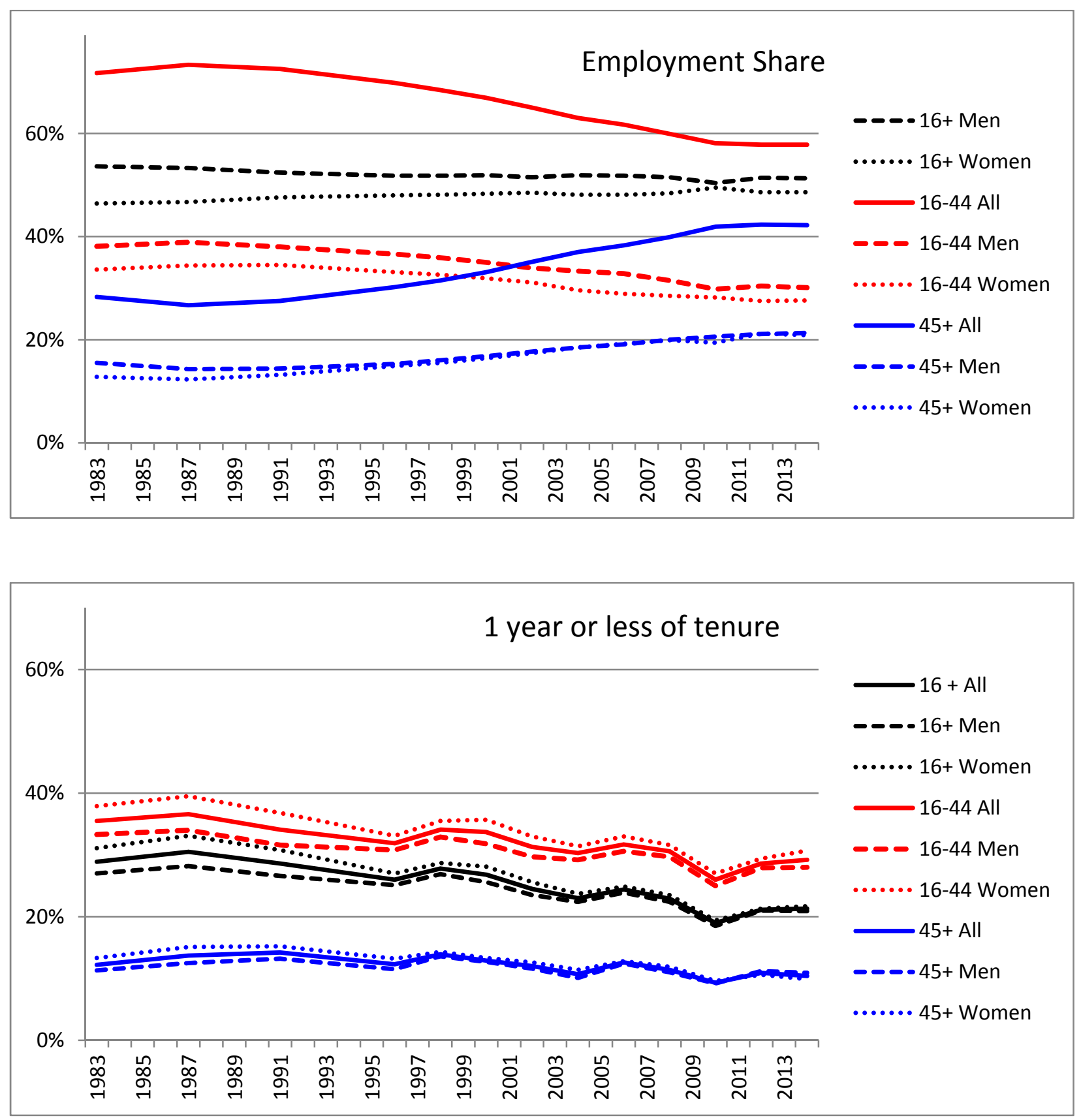
Figure A1: Employment and Tenure Data, 1983-2014, by Age and Gender (continued)
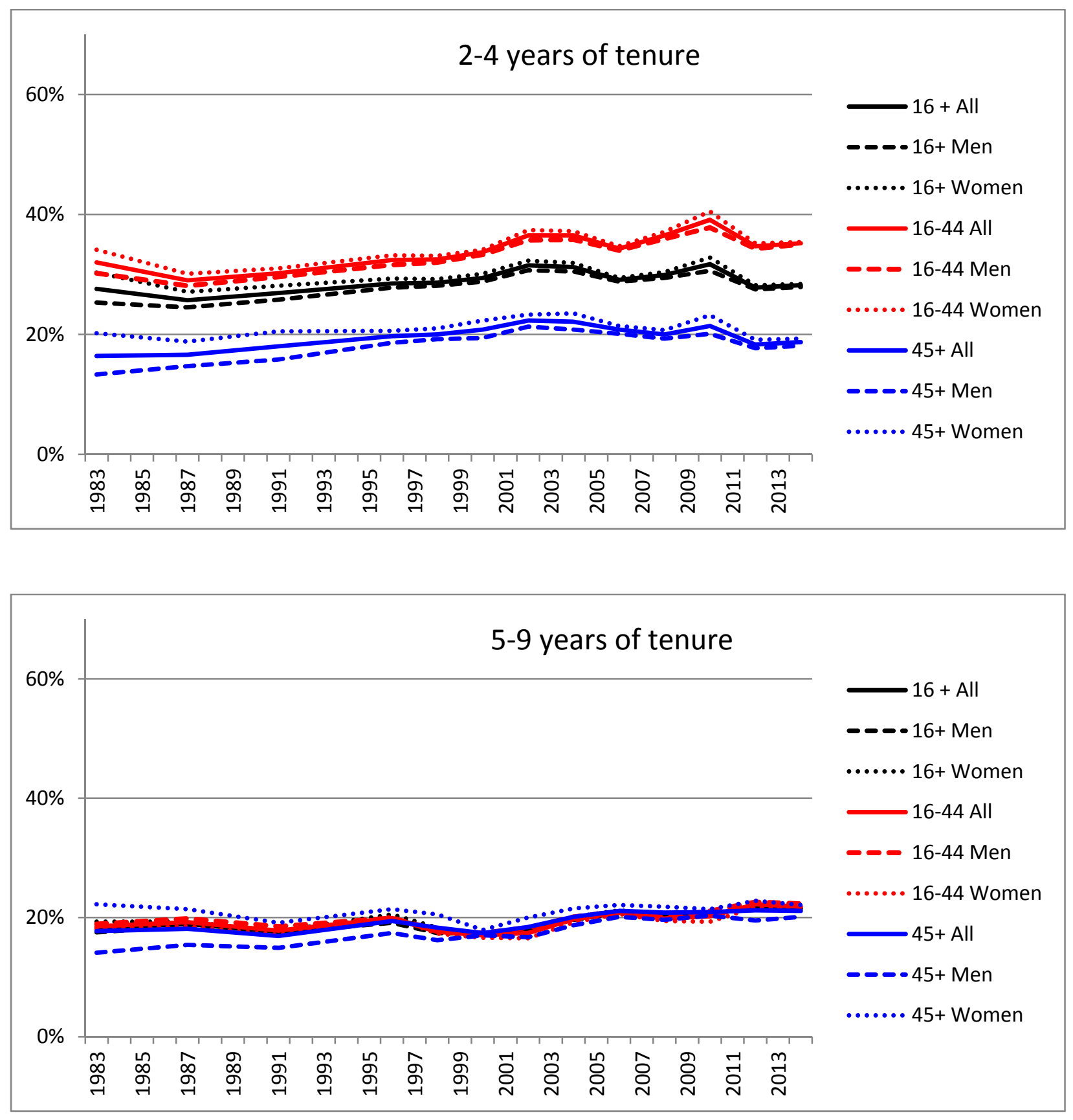
Figure A1: Employment and Tenure Data, 1983-2014, by Age and Gender (continued)

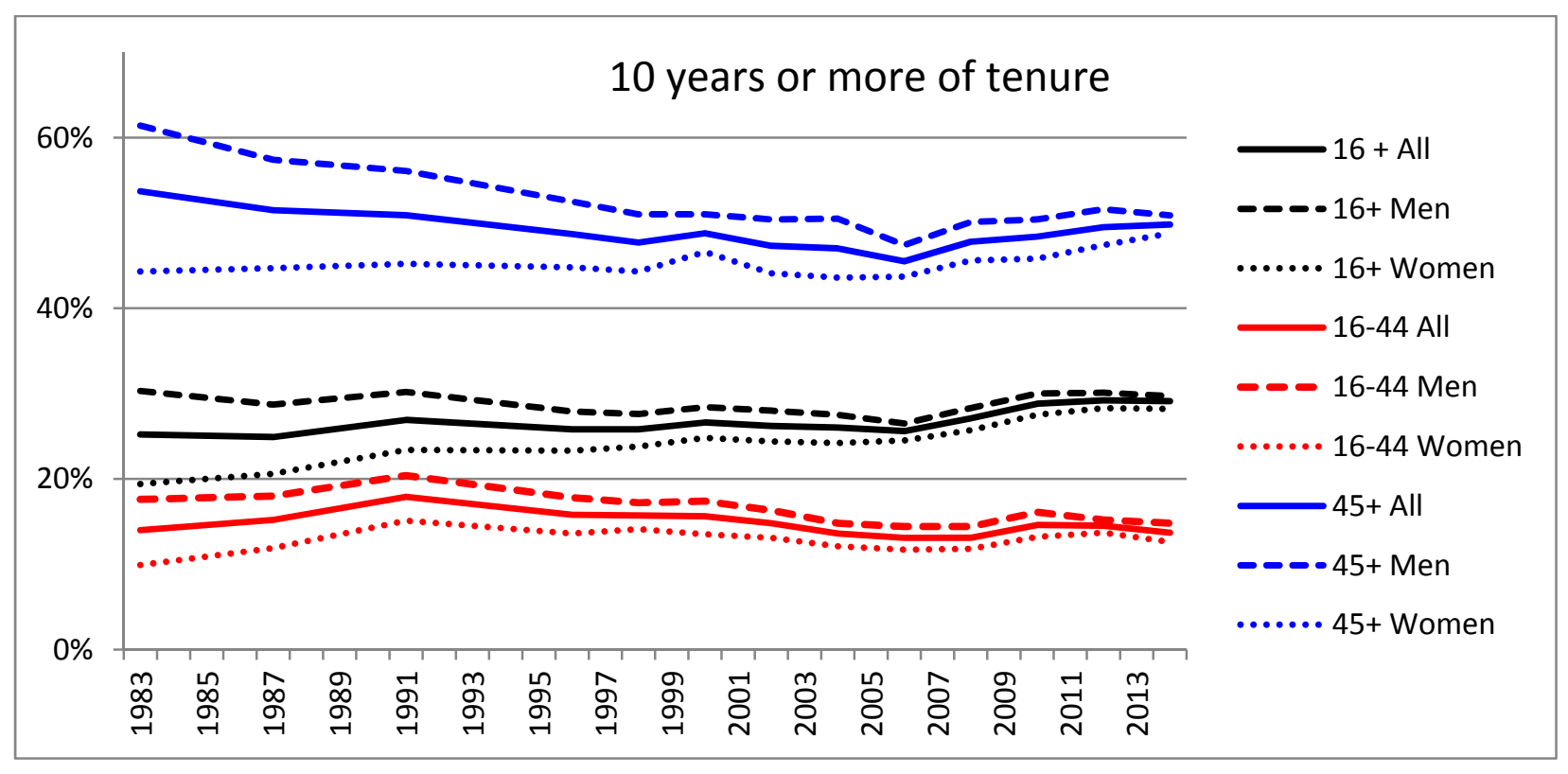


Figure A2: Real Weekly Earnings by Tenure, 1996-2014

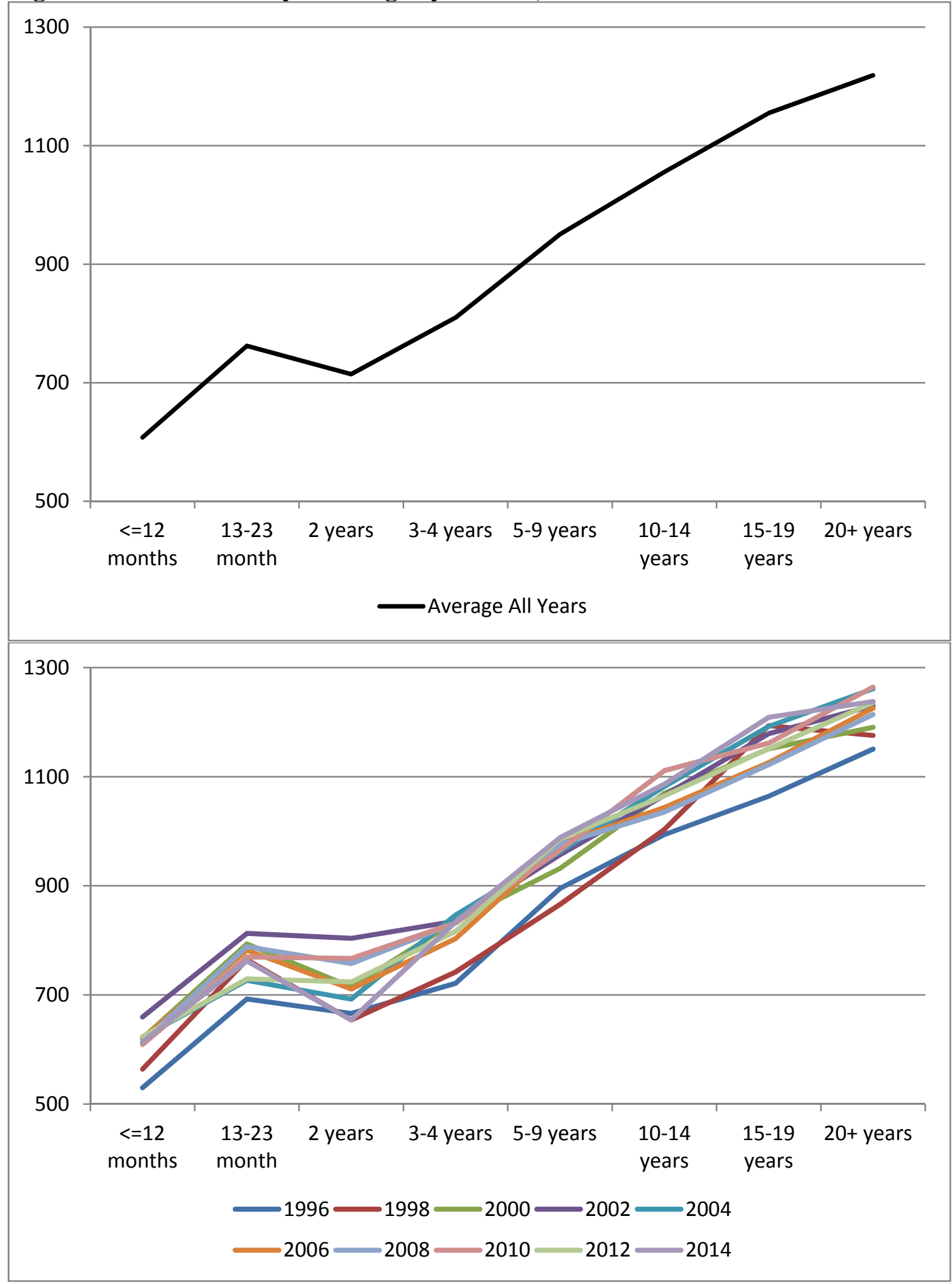

